\title{
Vagrancy Concepts in Welfare Law ${ }^{\dagger}$
}

\author{
Margaret $K$. Rosenheim*
}

TN A RECENT SERIES OF ARTICLES exhaustively discussing "California's

1 Dual System of Family Law," Professor Jacobus tenBroek states a persuasive case for concluding that vagrancy concepts infuse the welfare system, and thus the fanily law of the poor-so nuch of which appears in welfare statutes. It is his contention that vagrancy concepts are maintaming a firm hold on life within the welfare system, even though their tenure in criminal law appears to be in jeopardy. He concludes that "the relationship of the poor law and other public aid provisions to the vagrancy statutes is as intiniate today as it was in the time of the Tudors."

In this paper I attempt to support my basic agreement with tenBroek's thesis. This requires a look at vagrancy as a criminal offense and at the development of welfare laws which aim to accomplish the same ends. The discussion suggests policy issues which perneate the historical development of the vagrancy idea and pose hard choices to present-day legislators, administrators, and other policymakers.

\section{I}

PRELTMTNARY OBSERVATIONS

The very term vagrancy has an old-fashioned ring to it these days. Like the vagabond or beggar, the vagrant has disappeared fronl public view. But if his press releases are rare and generally unfavorable it cannot be said that he plays no role in modern criminal and welfare law systems; it is rather that he plays bit parts of which the general public is unaware and the professions dealing with him are quietly ashamed. ${ }^{3}$

$\dagger$ The fugitive character of many materials relied on in this article attests to my extraordinary dependence on a number of administrators and critics of social welfare. I gratefully acknowledge help from Miss Elizabeth Wickenden of the National Social Welfare Assembly, Miss Mary Claire Johnson and Mrs. Janet Kablert of the Tllinois Department of Public Aid, and staff members too numerous to identify in the U.S. Department of Health, Education, and Welfare, the U.S. Department of Labor, and the Office of Economic Opportunity. Public aid staff in several states also generously supplied me with information as did many colleagues, and I am greatly indebted to Barry Roberts for research assistance. Errors of fact or interpretation remain, however, solely my responsibility.

* J.D., University of Chicago. Professor, School of Social Service Administration, University of Chicago.

1 tenBroek, California's Dual System of Family Law: Its Origin, Development, and Present Status (pts. 1, 2), 16 Stan. L. Rev. 257, 900 (1964); (pt. 3), 17 Stan. L. Rev. 614 (1965) [hereinafter cited as tenBroek with appropriate volume and page].

2 tenBroek, 17 Stan. L. Rev. 675.

${ }^{3}$ Among the more outspoken critics of the crime of vagrancy should be numbered 
Who is the vagrant? It is difficult to answer this basic inquiry and to discuss intelligibly the problems associated with vagrancy because of the amorphousness of the concept. Vagrancy has covered a variety of acts and statuses in the course of its history in England and the United States. Furthermore, the use to which vagrancy concepts have been put, in criminal law or in association with poor relief of either ancient or modern type, has shifted according to the compelling economic and social requirements of the times.

\section{A. The Crime of Vagrancy}

\section{England}

Discussions of vagrancy typically hark back to Sir James Fitzjames Stephen's identification of three stages-vagrancy as the criminal aspect of the poor law, as a crime of status, and as a crime of conduct. ${ }^{4}$ An intertwining of criminal and welfare law approaches is discernible throughout six hundred years of history, the interaction varying according to Parliament's response to the changing economic and social problems of the times.

The first stage runs from 1349 to 1547. Starting with the Statutes of Laborers ${ }^{5}$ and proceeding into the fifteenth century the vagrant emerges

Douglas, Vagrancy and Arrest on Suspicion, 70 YALE L.J. 1 (1960); Foote, Vagrancy-Type Law and Its Administration, 104 U. PA. L. Rev. 603 (1956); Lacey, Vagrancy and Other Crimes of Personal Condition, 66 HaRv. L. Rev. 1203 (1953); Sherry, Vagrants, Rogues and Vagabonds-Old Concepts in Need of Revision, 48 CALIF. L. REV. 557 (1960); Note, 37 N.Y.UL. REv. 102 (1962). Their comments range over the ineffectiveness of vagrancy prosecutions to achieve crime prevention, substantive questions of constitutionality and statutory interpretation, and the differential enforcement of vagrancy laws. To these may be added the point that some aspects of vagrancy enforcement may overburden the criminal justice system "with functions it cannot effectively perform [thereby diverting] . . . energies and resources from those vital functions of public order that the criminal law, and only the criminal law, can perform." Allen, The Borderland of the Criminal Law: Problems of "Socializing" Criminal Justice, 32 SocraL Service Rev. 107, 110 (1958), reprimted in Atien, The Borderdand of Criminat Justice 7 (1964). Critics of the welfare system's treatment of the vagrant are cited in later sections of this article.

${ }^{4}$ See 3 Stephen, History of the Crtuminat Law of Encrand 266-75 (1883).

$523 \mathrm{Edw} .3$, c. 1-8 (1349); $25 \mathrm{Edw} .3$, c. 1-7 (1350). The first statute is usually considered to mark the starting point of the modern relief system. Its objectives were maintenance of wages at the level prevailing prior to the Black Death, enforcement of the customary terms of services in the face of marked tendencies to migrate for employment, and prohibition of almsgiving to be able-bodied. The Statute directed that:

every man and woman ... of what condition he be, free or bond, able in body, and within the age of threescore years, not living in merchandize, nor exercising any craft, nor having of his own whereof he may live, nor proper land, about whose tillage he may himself occupy, and not serving any other . . . shall be bounden to serve him which so shall him require. And take only the wages, livery, meed, or salary, which were accustomed to be given in the places where he oweth to serve .... Statute of Laborers, 1349, 23 Edw. 3, c. 1. 
as a stranger and wanderer who threatened the demise of a crumbling feudal society. ${ }^{6}$ Regulation of wages and prices and prohibition of wandering were the measures adopted to prevent the exploitation of a short labor supply, greatly depleted by the Black Plague, and to maintain the status quo in which roles and responsibilities were clearly defined. Laborers were curbed under penalty of law from departing from their customary places of employment without letters proclaiming the legitimacy of their travels. Employers, too, for a time, were penalized for paying wages above scale. Vagrancy control had a clear economic objective.

Even in this early stage, however, other factors emerged to shape the legislation. Crime prevention, for one, was soon identified as a reason for prohibiting wandering and begging. ${ }^{8}$ The unattached stranger lacking visible means of support was seen as a predator, a threat to public safety. Repressive measures directed at him increased in number and severity throughout most of this period. ${ }^{9}$ Begging was early restricted

Penalties were exacted of both giver and taker for failure to comply with the terms of the law. The second Statute of Laborers sought to promote comphance by detailed prescription of wages and other terms of service.

6 Successive enactments throughout the latter half of the fourteenth and the fifteenth centuries attest to the insufficiency of the Statutes of Laborers to attain their stated goals. Chief among the acts of Parliament are: 12 Rich. 2, c. 7 (1388), distinguishing the impotent from the able-bodied poor with implied permission for the former to beg; 2 Hen. 5, c. 4 (1414), conferring summary powers on the justice of the peace with respect to violations of laws controlling labor; and 11 Hen. 7, c. 2 (1494), permitting confinement in the stocks to be substituted for jail. General discussions of the legislation are available in DE SchweINITZ, England's ROAd to Soctad SecurIty 1-13 (1943); 1 NICHolis, History of THE ENGLISH POOR LAW 1-106 (1854) [hereinafter cited as NICHOLIS]; and 3 StepHEN, op. cit. supra note 4 , at $266-69$.

7 Statute of Laborers, 1349, 23 Edw. 3, c. 3: "that no man pay, or promise to pay, any servant any more wages, hveries, meed, or salary, than was wont .... Nor that in any other manner shall demand or receive the same, upon pain of doubling of that, that so shall be paid, promised, required, or received, to hin which thereof shall feel himself grieved, pursuing for the same." Penalties on employers were removed by 4 Hen. 5 , c. 4 (1416). See 1 Nrcholls 72-73.

8 Nicholls, Poor Law Commissioner turned historian, sees repression of vagabondage and vagrancy as the primary purpose of the early laws: "Many of those who had struggled for and asserted their own freedom, resorted to begging and vagabondism, and not infrequently to violence, whenever employment, or the means of honest livelihood, was not readily obtainable, and sometimes, perhaps, when it was. The idle and evil-disposed were of course the first to do this, and the unsettled character of the period fostered and gave licence to the vocation of a beggar, which, moreover, received direct encouragement from the almsgiving inculcated by churchmen, and practised by the religious communities." 1 Nichorrs 31-32.

9 Nicholls notes that the alternation between severe and more lenient measures of vagrancy control, evident in later eras, was discernible in the fifteenth and sixteenth centuries. Id. at 98-99, 104-05, 119, 134-35, 185-88, 200-01. 22 Hen. 8, c. 12 (1530), marks the beginning of rehance on mutilation for "undesirables," such as charlatans. See 3 STEPHEN, 
to the "impotent poor," as a poor relief measure while closing this avenue of recourse to either the laborer whose search for employment failed or the able-bodied person bent on a life of indolence or crime. By the dawn of the great Tudor period crime prevention had becoine a primary object of vagrancy laws.

Second, the emergence of a secular poor relief system had consequences for vagrancy. The break-away of the able-bodied from serfdom inevitably produced failures and brought with it the recognition of poverty and want as appropriate subjects of national policy. ${ }^{11}$ One indispensable ingredient of an effective assault on extreme poverty and suffering was organized public relief. Whether relief was dispensed under the auspices of the medieval church or under secular administration, as occurred during the Tudor reign in England, an effective relief scheme had to comprehend the entire jurisdiction, distinguish at least to some degree ainong the types of poverty and the measures appropriate to relieve each type, and contain an element of coinpulsion so far as donation was concerned. All these elements were present in canon law. ${ }^{12}$ They later appeared as secular commands in the sixteenth-century statutes which led up to the famous Elizabethan Poor Law in 1601..$^{13}$

op. cit. supra note 4, at 271 . Enslavement, banishment, and impressment came later. Id. at 271-73.

10 The distinction between able-bodied and impotent poor was first introduced in 12 Rich. 2, c. 3 (1388), whereby a person able to serve is commanded to remain and labor "in the hundred, rape or wapentake where he is dwelling" and "beggars impotent to serve" are directed to remain where resident or born. This statute provided no rehief for the impotent (probably because church law already provided a poor rehief system; see Tterney, Medieval Poor LAW 129 (1959)) but the prohibition against begging was imited to the able-bodied. This statute also contained the germ of the law of settlement, it should be noted. Ibid. Direct relief of the impotent poor is first statutorily prescribed in $27 \mathrm{Hen} .8$, c. 25 (1535).

111 Nicrouls 68.

12 The presence of these elements has often been overlooked with the result that poor relief legislation is commonly dated from the sixteenth century. Tierney argues that "the occasional fragments of secular legislation that one comes upon in the medieval period, insofar as they related to the relief of poverty and not to the suppression of vagrancy, were almost invariably inere reenactunents of principles drawn from the canonistic works which contained the main body of medieval law in the field. . . Medieval canon law is no obscure eddy, outside the main stream of poor law history, but an important and neglected stretch of the main stream itself." TrePNEXY, op. cit. supra note 10, at 5-6. Authorities differ on the extent to which canon law was effectively implemented. Whereas Jordan characterizes the "medieval system of alms" as "at once casual and ineffective in its incidence," JoRDaN, Partantaropy In ENGLAND 1480-1660, at 17 (1959), Tierney states that an archdiaconal visit in 1520 found the provision of parochial poor rehef "tolerably satisfactory" in 158 of 193 parishes, TIERNEX, op. cit. supra note 10, at 128. In the latter's view the system's greatest shortcoming was the failure "to develop a constructive approach to the problem of the ablebodied unemployed ...." Id. at 132 .

1343 Eliz. I, c. 2 (1601). A succinct and penetrating analysis of Tudor poor law development in relation to vagrancy control and the system of labor exchange is available in 
With the introduction of poor relief based on taxation and secular administration the interconnections between control of vagrancy and the function of public aid were temporarily loosened. As the poor relief system extended its scope and powers it commanded techniques for dealing with the able-bodied poor. ${ }^{14}$ Certain types of vagrants were dealt with by the welfare system, leaving others to the criminal law.

Thus 1547 is considered to mark the beginning of the second stage in vagrancy history; ${ }^{15}$ vagrancy became a crime of status to be employed as a weapon against beggary —at times a national disgrace ${ }^{16}$ - and other

tenBroek, 16 Stan. L. Rev. 258-79. See Leonard, The Earry History of Enguish POOR RELIEF (1900), for an account of legislation and administration from 1500 to the 1680's. A convenient summary of Tudor legislation is available in DE SCHWEINTTz, op. cit. supra note 6, at 20-29. 1 Nichorrs 1-210, discusses all euactments from Athelstan to James I. A standard reference is Webb \& WebB, English Locai Governarent: ENGLisH Poor LAW Historx, ParT I: The OId PoOr LAW (1927). The major statutes are 27 Hen. 8, c. 25 (1535), ordering alms to be collected for relief of the impotent and for putting to work the able-bodied poor; 14 Eliz. 1, c. 15 (1572), introducing taxation; 18 Eliz. 1, c. 3 (1576), defining purposes of work relief and maugurating the principle of relatives' responsibility in the bastardy provisions; and 39 Eliz. 1, c. $3 \& 4$ (1597), establishing overseers of the poor, authorizing erection of houses of correction, extending relatives' responsibility, and strengtheming administrative machinery.

${ }^{14}$ By the time of the codification in 1601, 43 Eliz. 1, c. 2, the poor law made available tax funds for the impotent and charged the overseers of the poor with apprenticing or punishing, or purchasing work stuffs ("a convement stock of flax, hemp, wool, thread, iron and other necessary ware and stuff") for employment of the able-bodied as their ages, conditions, and attitudes might require. See 14 Eliz. 1, c. 5 (1572); 18 Eliz. 1, c. 3 (1576); 39 Eliz. 1, c. 1-5 (1597); WEBB, op. cit. supra note 13, at 54-59. Accounts of the developing national policy toward poverty and unemployment in the sixteenth century are also available in Jordan, op. cit. supra note 12, at 77-101, and tenBroek, 16 Stan. L. Rev. 258-91. Prior to 39 Eliz. 1, c. 3 (1597), exphicitly directing the overseers to provide work for the able-bodied unemployed, the choices open to such persons were narrow. Jordan notes a proposed statute for a public works program drafted in 1531, JoRDAN, op. cit. supra note 12, at 84, but it appears that institutionalized publicly-financed work programs (as distinct from compulsory labor in the House of Correction) were a late seventeenth-century innovation in England. See dE SCHWEINTTz, op. cit. supra note 6, at 47; LEONARD, op. cit. supra note 13, at 221-36. However deficient the administration of work provisions the notable fact is that rehef was no longer demied to the able-bodied, whereas today public assistance may be unavailable to the able-bodied or available in less adequate measure than is the case for groups of unemployables receiving public support. See text accompanying notes 37-38 infra.

151 Edw. 6, c. 3 (1547). Penalties provided included branding, slavery, and death.

10 Jordan paints a vivid picture of the social dislocations of the late fifteenth and early sixteenth centuries which gave rise to the stream of legislation. JoRDAN, op. cit. supra note 12, at 59-65, 67-76, 78-86. And see LEONARD, op. cit. supra note 13, at 11-21, detailing causes of reform of the poor relief system in England and on the Contiment. As Leonard notes, the countries of Western Europe were equally infested by a "plague of vagrants" whose vagaries troubled a number of contemporary writers. $I d$. at 13 . Thus it was written in 1494:

Bold begging charms full many a fool, For begging lias become the rule 
conduct regarded as threatening or reprehensible. Now that poor relief was an accepted public responsibility buttressed by taxation and formal assignment of duties of administration, the vagrant no longer was identified primarily as a wanderer in search of employment. He became instead an object of control because of his roguery, his threat to public security, his flaunting of prevailing moral values. By an act of 1744 , consolidating and extending prior enactments, the crime of vagrancy encompassed idle wanderers, beggars, persons pretending to be seafarers, persons "wandering in the habit or form of Egyptians," and persons running away from their wives and children. It grouped the offenders into three classes, the disorderly, rognes and vagabonds, and incorrigible rognes, and assigned a specific punishment to each. ${ }^{17}$ Status and conduct were intermingled in the vagrancy definition, the apparent object being to control persons thought likely to commit crimes as well as persons whose behavior was offensive to prevailing moral values.

In the third stage, dated from 1824, vagrancy concepts deriving from

And ranks among our best professions:

To beg some men will always choose,

Though they could work if but they would,

They're young and strong, their health is good,

Save that their back they'll not inchine,

These sluggards have a corpse's spine.

2 Brant, SHuP of Foors 208-09 (Zeydel transl. 1944). Adaptations of Brant, published in 1509, did full justice to his disapproval of begging. See, e.g., I BRANT, SHIP of Foovs 301-06 (Barclay transl. 1874). A century later, a distinguished foreign visitor expressed relief and satisfaction at the reduction of begging in England and gave a plausible explanation of the cause: "It is a pleasure to go about [at the Royal Exchange] for one is not molested or accosted by beggars, who are elsewhere so frequently met with in places of this kind. For in all England they do not suffer any beggars except they be few in number and outside the gates. Every parish cares for its poor. Strangers are brought to the hospital, but those that belong to the Kingdom or have come from clistant places are sent from one parish to another, their wants being cared for, till at last they reach their home." Diary of the Duke of Stettin's Journey (1602), quoted in 2 TREVELYAN, HISTORY OF ENGLAND 124 (3d ed. 1945).

1717 Geo. 2, c. 5 (1744); see 3 STEPHEN, op. cit. supra note 4, at 272-73. Nicholls observes that "vagrancy, mendicancy, and pauperism are so mixed up together, that it is not surprising the earker statutes should have applied to them indifferently, and that it was not until a late period, and after a special provision lad been made for the relief of the destitute poor, that vagrants were dealt with as a separate class ...." 2 NicHoLrs 208. The arrival of gypsies in England may have hastened the identification of a crimepreventive function of vagrancy. Gypsies were first included among the idle persons histed in a vagrancy statute in 1530, 22 Hen. 8, c. 12 , the same year in which a law prohibiting their entry into the kingdom was enacted, 22 Hen. 8, c. 10. I am indebted to Professor David Matza of the Umiversity of California, Berkeley, for calling to my attention the possibility that fear of gypsies was a significant reason for expanding vagrancy concepts in the sixteenth, seventeenth, and eighteenth centuries. Cf. Chambliss, A Sociological Analysis of the Law of Vagrancy, 12 Social Probtems 67 (1964). 
status were pruned from the criminal law of England. ${ }^{18}$ The final excision occurred in 1937 in Ledwith $v$. Roberts, which made reasonable cause to suspect proscribed acts had been committed a requirement for vagrancy arrest. $^{10}$

\section{The United States}

Here, as tenBroek states, the stages in vagrancy development of the poor law penal aspect, crime of status, and crime of conduct "have not been successive but simultaneous." 20 There are two major sources of vagrancy concepts in current law, the criminal law and the welfare law. The intermingling of crimes of status and of conduct is readily apparent in criminal statutes on vagrancy. In a number of states the vagrancy definition includes not only a person committing such acts as begging, prostitution, disorderly conduct, and desertion but also a person with the status of idleness, dissolute misspending of time, habitual drunkenness, association with thieves or prostitutes, and the like. ${ }^{21}$ No longer a keystone of labor legislation, vagrancy occupies a subsidiary role in criminal law, joining the lists of petty crimes. But in numbers affected it remains significant, ${ }^{22}$ and it provides avenues for officialdom to protect society against "moral pestilence" and to serve such diverse humane ends as giving shelter to the aged or drying out alcohohics when alternative remedies are not readily available. ${ }^{23}$

Criticism by legal theorists has been almost uniformly directed to clarifying the several purposes served by such laws. ${ }^{24}$ Questions have been raised both as to the theory and implementation of the laws. They are attacked as unconstitutional on the grounds of vagueness, unreasonableness of classification, and discriminatory enforcement; they are said to be inadequate to meet the goal of crime prevention-often an express justification for their existence.

One can hazard the guess that the days of the "old-style" crime of vagrancy are numbered. ${ }^{25}$ Some modern criminal codes omit vagrancy

185 Geo. 4, c. 83 (1824). Although concepts reminiscent of status are embodied in this act, the emphasis is placed on conduct. See 3 STEPHEN, op. cit. supra note 4 , at 273.

10 Ledwith v. Roberts, [1937] I K.B. 232, 275-77 (C.A. 1936).

20 tenBroek, 17 STAN. L. REv. 671-72.

21 Note, 37 N.Y.UL. REv. 102, 108-14 (1962).

22 Id. at 102 n.3, citing FBI, UNIFORAC CRIME Reports 101 (1959).

23 Foote, supra note 3 , at 631-37; Lacey, supra note 3 , at 1217-19.

24 See authorities cited at note 3 supra. But see Perkins, The Vagrancy Concept, 9 Hastings L.J. 237 (1958).

25 A writ of certiorari was granted by the Supreme Court to a party challenging the District of Columbia vagrancy ordinance as void for vagueness, Hicks v. District of Columbia, 379 U.S. 998 (1965), but was subsequently dismissed as improvidently granted, 86 Sup. Ct. 798 (1966). 
as a distinct offense, seeking to achieve control of that behavior which is widely deplored and deemed harmful to society by more direct means. Thus the Mllinois criminal code discards vagrancy but retains the crimes of gambling, prostitution, keeping of disorderly houses, disorderly conduct, and pimping. ${ }^{26}$ Similarly, the Model Penal Code, in section 250.2 (Disorderly Conduct) subsumes certain vagrancy-type offenses regarded as socially dangerous. ${ }^{27}$ Conduct harmful simply to the actor is omitted. We may expect this trend to continue.

But before congratulating ourselves on the abolition of a crime widely condemned as outdated and inevitably presenting opportunities for grossly discriminatory enforcement, we must ask if any unfinished business remains. Is it true, as tenBroek claims, that "this class of offenders, for such they are still regarded, has simply moved along with penal sanctions to the welfare program"? ${ }^{28}$ And if the claim can be supported, does the incorporation of vagrancy concepts in welfare law raise issues comparable to those identified with the crime of vagrancy?

\section{B. Modern Welfare Programs}

The suggestion that the spirit of vagrancy offenses lingers on in the modern welfare system inay come as a surprise to inany. On the face of it this system is established to achieve goals which are remote from the policies that historically have governed vagrancy. Vagrancy-type offenses reach certain kinds of personal conduct. We are not accustomed to thinking of the availability of public support and services as predicated on the proof of worthiness or the absence of immoral or imprudent conduct. Nor would we usually characterize the welfare system as seeking to curtail labor mobility, as did the vagrancy law in an early period. Population mobility is, indeed, an accustomed and valued feature of American society, notwithstanding the problems attendant on attaining it to a high degree. One considerable virtue of Old-Age, Survivors, and Disability Insurance, in fact, is that it affords coverage anywhere in the United States regardless of the number of changes of employment a worker may experience.

It is perhaps precisely the widespread knowledge and acceptance of OASDI which impedes recognition of the policies and problems associated with other prograins that are also part of the welfare system. The importance of OASDI and Medicare deflects popular attention from other component parts. Elsewhere in this Symposium the components of the

26 III. Laws 1961, at 2044, repealing Irc. Rev. Stat. ch. 38, § 270 (1957); IrL. Rev. STAT. ch. 38, §§ 28-1, 11-14, 11-17, 26-1, 11-19 (1965).

27 Model Penal Code $\$ 250.2$ (Proposed Official Draft 1962).

28 tenBroek, 17 Stan. L. Rev. 675. 
entire welfare system are described and the major trends, shortcomings, and conflicts identified. ${ }^{29}$ Here it is appropriate to stress only the welfare programs which incorporate vagrancy concepts-those programs which inake provision for support of the able-bodied and their dependents. Thus this article focuses on public assistance, ${ }^{30}$ with specific reference to general assistance and Aid to Families with Dependent Children (AFDC), and to a far lesser degree on unemployment insurance.

The selection of these categories follows naturally from the thesis that the accommodation of the needs of able-bodied persons in a system of social provision puts that system to its severest test. ${ }^{31}$ To the extent that the spirit of vagrancy hovers over the welfare system at all, its corporeal manifestations occur in those programs which provide financial rehef to people in an age group which contains the bulk of the producers in our economy. This same age group harbors those whose immoral or otherwise aberrant behavior is perceived as the greatest threat to society, in part because of the realization that the behavior may interpose obstacles to fulfilling an expected economic role. Thus an unmarried mother receiving AFDC may, by her sexual conduct, be burdened with additional illegitimate children who interfere with her assunption of an economically productive role, a role increasingly borne by women in modern society. Likewise, the apathy or lack of job skills of a male aged forty which result in unemployment is of greater consequence than the same limita-

29 Wedemeyer \& Moore, The American Welfare System, this symposium.

30 Modern critiques of welfare laws demonstrate thorough awareness of the punitive character of many of these laws. Students of social welfare have never lost sight of poor law's dominant influence upon general assistance. The broad recognition of poor law influences in federally-aided public assistance, however, is probably of fairly recent origin, for these programs, established in 1935, with their emphasis on rights, hearings, unrestricted unoney payments, etc., bore little superficial reseniblance to old-style poor relief. See U.S. Bureau of Public Assistance, Soctal Security Bd, Money Paymants to Rectpients of Ond-Age Assistance, Am to Dependent ChIndren, and Am to the Binnd (Bureau Circular No. 17, 1944); Ball, Social Insurance and the Right to Assistance, 21 Sociar SERvice Rev. 331 (1947). But see Note, Abolish the Means Test for Old Age Assistance, 17 Soctar Service Rev. 213 (1943); cf. Smith, Elements of the Judicial in Security Programs, 17 Soctar Service REv. 424 (1943). The changing view of public assistance is no doubt attributable to innumerable factors, ineluding growing knowledge of administrative abuses and inconsistencies, professional criticism of individualized, therapeutically-directed techniques for relief of economic need, and increasing support for impersonal generalized methods of income maintenance. See generally KeTTH-LoCAS, Decrsions ABOUT PeOPLE IN NEED (1957) ; Bentrup, The Profession and the Means Test, Social Work, April 1964, p. 10; Kahn, Social Services in Relation to Income Security, 39 SocIaL SERvice Rev. 381 (1965); Mencher, Perspectives on Recent Welfare Legislation, Fore and Aft, Social Work, July 1963, p. 59; Reich, The New Property, 73 YaLE L.J. 733 (1964); Reich, Individual Rights and Social Welfare: The Energintg Social Issues, 74 YaLE L.J. 1245 (1965); Schwartz, A Way to End the Means Test, Social Work, July 1964, p. 3.

31 For an illuminating discussion of income maintenance policies respecting the ablebodied, see Burns, Social Security and Pubitc Poticy 56-79 (1956). 
tions in one of seventy. Thus the vagrancy concepts discernible in modern welfare programs are primarily those with an economic flavoridleness and wandering without visible means of support, desertion of family whose members become public charges, illicit intercourse which results in additional children. The criminal types of vagrancy, by comparison, have hittle carryover into welfare practice.

What, then, are provisions for the able-bodied-or persons who are so regarded by the public? They may be classified as public assistance for the unemployed adult male and his dependents and for mothers of dependent children. A social insurance program for the unemployed may be added to the hist. Note should also be taken of the increasing availability of job training programs and other services which; in addition to protective features, afford an avenue of income support.

The genesis of these modern programs, for all practical purposes, is the poor law and earlier religious institutions on which it built. As we have seen, the able-bodied idler or wanderer was an unwelcome challenge even then. The medieval observer scarcely knew what to make of the vagrant. Both canomists and secular lawmakers seem to have ignored the inportant distinction between various kinds of able-bodied persons and were content with an elementary, though admittedly significant, differentiation between able-bodied and impotent. ${ }^{32}$ Nonetheless, the Elizabethan Poor Law, while lacking a sophisticated classification of the stalwart, had at least the considerable merit of affording a total and flexible nationwide system of relief. In the accretions of sixteenth-century legislation parish officials gained a rich variety of measures which permitted them to deal with the varying problems of the able-bodied..$^{33}$ Thus distinctions absent in theory could, if desired, be drawn in practice.

Unfortunately, by this test, our present welfare system must be graded as deficient. In a line of direct descent from their English forebears, the able-bodied still wear the mantle (or the rags) of the sturdy beggar, and in some respects public provision for their relief is less adequate than four hundred years ago. This judgment is supported by examination of current programs.

The legacy of the poor law approach is most apparent in the public assistances, for these programs, like their ancestor, are based on proof of need. One class of public assistance programs, and the most important as measured by numbers and expenditures, is the categorical assistances. These programs are based on grants-in-aid established in the Social

32 Tierney comments on the failure of the canonists to undertake a badly-needed "scholastic critique of employability in able-bodied vagrants"-to distinguish those who were idle, unable to find work, looking for better work, or intermittently employed. TIERNEY, op. cit. supra note 10, at 119; see $i d$. at 119-20, 128-32.

33 See note 14 supra. 
Security $\mathrm{Act}^{34}$ and presently include the aged, blind, disabled, families with dependent children, and medical assistance titles. ${ }^{35}$ With the exception of the medical programs, categorical assistance is geared to the unemployable. By their nature these categories rest on federal-state legislation and combinations of financing from federal, state, and sometimes local governments. ${ }^{30}$ The other type of assistance program is general assistance, the most "residual" of all residual programs but nevertheless not comprehensive in every state of the needy left out of the other programs. ${ }^{37}$ The latter aspect deserves emphasis. Since able-bodied men typically are omitted from coverage under the categorical assistances,

3449 Stat. 620 (1935), as amended, 42 U.S.C. $\$ \S 301-1394$ (1964), as amended, 42 U.S.C. $\$ \$ 302-1396 \mathrm{~d}$ (Supp. I, 1965).

35 Social Security Act, Subchapter I, Grants to States for Old-Age Assistance and Medical Assistance for the Aged [hereinafter cited as OAA and MAA], 49 Stat. 620 (1935), as amended, 42 U.S.C. $\$ \S 301-06$ (1964), as amended, 42 U.S.C. $\$ \S 302-06$ (Supp. I, 1965); Subchapter IV, Grants to States for Aid and Services to Needy Families with Children [hereinafter cited as AFDC], 49 Stat. 627 (1935), as amended, 42 U.S.C. $\$ \$ 601-09$ (1964), as amended, 42 U.S.C. $\S \S 602-06$ (Supp. I, 1965); Subchapter X, Grants to States for Aid to the Blind [hereinafter cited as AB], 49 Stat. 645 (1935), as amended, 42 U.S.C. $\$ \S 1201-06$ (1964), as amended, 42 U.S.C. $\$ \S 1202-06$ (Supp. I, 1965); Subchapter XIV, Grants to States for Aid to the Permanently and Totally Disabled [hereinafter cited as APTD], 64 Stat. 555 (1950), as amended, 42 U.S.C. $\$ \$ 1351-55$ (1964), as amended, 42 U.S.C. $\$ \S 1352-55$ (Supp. I, 1965); Subchapter XVI, Grants to States for Aid to the Aged, Blind, or Disabled, or for such Aid and Medical Assistance for the Aged [hereinafter cited as combined category], 76 Stat. 197 (1962), as amended, 42 U.S.C. $\$ \$ 1381-85$ (1964), as amended, 42 U.S.C. $\$ \$ 1382-85$ (Supp. I, 1965); and Subchapter XIX, Grants to States for Medical Assistance Programs [hereinafter cited AMI], 79 Stat. 291, 42 U.S.C. $\S \S 1396-96 \mathrm{~d}$ (Supp. I, 1965). As of August 1965, the public assistance caseloads were: OAA, $2,144,534$ recipients; MAA, 264,687; AB, 95,135; APTD, 563,113; AFDC, 4,388,240 (in over one million families). Persons on general assistance (GA) totalled 662,000 . See Welfare in Review, Dec. 1965, p. 26, Table I.

36 The percentage of federal funds expended on public assistance grants, services, training, and administration ranges from a low of $40 \%$ (Nevada) to a high of $78.6 \%$ (Mississippi) for the categories. A breakdown by categories reveals that the highest proportion of federal funds is expended in OAA (64.3\%) and the lowest in $\mathrm{AB}(48.3 \%)$. Bureau of Family Services, U.S. Dep't of Health, Educ. \& Welfare, Source of Funds Expended fiscal year ended June 30, 1964, Dec. 1964. The national average for assistance alone under the categorical programs is 56 per cent federal funds. For a listing of the assigned "federal" percentage and "federal medical" percentage for which each state was eligible as of 1964, see BUREAU OF Farmity Services, U.S. Dep't of Heatte, Educ. \& Welfare, Characteristics of State Public Assistance Plans: Generai Provisions-Eumgibitity, Assistance, Adumnistration 116 (Public Assistance Rep. No. 50, 1964) [hereinafter cited Cearacteristics of State Pians]. The federal percentage (that is, the basis for calculating reimbursement of money payments) ranged from $50 \%$ to $65 \%$, with 19 of the 51 jurisdictions affected by the formula receiving $50 \%$ matching and 16 receiving $65 \%$. The remaining 16 jurisdictions fell in between. A somewhat similar distribution applies to the states with respect to the federal medical percentage, a reimbursement formula running from 50\% to 80\% (50-83\% following 1965 amendments, 79 Stat. 351, 42 U.S.C. 1396d(b) (Supp. I, 1965)) matching on vendor medical payments (19 states receiving $50 \%$, 11 states $70-80 \%$ matching).

37 See generally Bureat of Publtc Assistance, U.S. Dep't of Heatte, Eddc. \& Welfare, Characteristics of General Assistance in the United States (Public Assistance Rep. No. 39, 1959) [hereinafter cited as Characterustics of GA]. 
their needs must be met under general assistance, if at all. We know, however, that the unemployed or underemployed are ineligible for income maintenance in a number of jurisdictions. ${ }^{38}$ Hence, certain needy persons do not, under the present system, have access to public support.

The able-bodied needy have another avenue of recourse in the face of adversity: unemployment insurance, a federally authorized, ${ }^{30}$ state-administered social insurance prograin. Instituted during the Depression as a counter-cyclical measure, it was never intended to cope with long-term unemployment. Thus for the idle and wandering vagrant it may be a wholly inadequate measure; not only is the duration of benefits limited but existing conditions of entitlement may also prove inpossible for him to fulfill. ${ }^{40}$

The third, and much newer, method of social provision for the ablebodied is the product of public concern over technological changes affecting employment and social factors affecting motivation to work. Emerging are programs of job training, basic literacy training, and employment "etiquette," all reflecting both economic and rehabilitative goals. ${ }^{41}$ With the vagrant in mind, we may conclude that these programs have particular relevance to the long-identified social problems refiected in vagrancy concepts. The idle person may well be one who cannot find work; on the other hand, he may lack incentive to seek employment or the personal capacity to retain it. In any case, he is an appropriate object of public concern. The types of social control and aid best calculated to resolve or minimize his difficulties are, however, subject to debate.

38 E.g., Artz. Rev. Stat. \& 46-233 (Supp. 1965):

A. No person shall be entitled to general assistance who does not meet and maintain the following requirements:

4. Is not employable according to the findings of the state department.

Part $B$ of the statute does allow for emergencies, however.

3049 Stat. 626 (1935), as amended, 42 U.S.C. \$§ 501-03 (1964).

40 He must work in a covered type of employment for a firm of specified size and/or a firm with certain size payroll; be able to, available for, and in most states actively seeking work; and be free of disqualifications, such as discharge for misconduct or voluntary quit. See generally BUREaU of EMPLoyment SECURITY, U.S. Dep'T OF Labor, Comparison of State Unemployadent Insurance Laws (BES No. U-141, 1966).

41 The Economic Opportunity Act of 1964 provides for work-training programs for unemployed young men and women, 78 Stat. 512, 42 U.S.C. \$ 2731 (1964), for part-time employment among students in institutions of higher education, particularly those students from low-income families, 79 Stat. 1249, 42 U.S.C. $\$ 2751$ (Supp. I, 1965), and for community action prograns, where the emphasis is to assist comnunities where unemployment and underemployment have given rise to poverty and related ills, 78 Stat. 518, 42 U.S.C. $\$ 2785$ (c) (1964). Under the Manpower Developnient and Traiming Act of 1962, training programs are to be devised for both the unemployed and underemployed, 79 Stat. 75, 76, 42 U.S.C. §§ 2572a, 2572c (Supp. I, 1965), with priority going to the unemployed, 76 Stat. 26, 42 U.S.C. § 2582 (c) (1964). Thus these newer programs are not in all instances restricted to the indigent or to the unemployed. 
It is within the context of social provision for the able-bodied poor that the carryover of vagrancy concepts should be examined. What is the function of vagrancy concepts in this setting? How appropriate are these ideas to the fulfillment of the various aims of the welfare system? Finally, are there alternative concepts available to guide the future growth of social policy?

II.

VAGRANCY CONCEPTS AND WELFARE IAW

To consider these questions fruitfully it is useful to look in some detail at selected welfare programs. In order to highlight the conflicting social values involved I examine the requirements of the programs according to sex and age. This may result in a certain overlapping in the treatment of programs but should ease the identification of issues which stem from the application of vagrancy concepts to different groups of needy persons.

\section{A. Welfare Law and the Male Vagrant}

The key element of vagrancy so far as men are concerned is quite plainly the idea of idleness and absence of visible support. Isolating this element amidst a plethora of other statuses and types of conduct comprehended in vagrancy laws, however, does not move us far forward. Immediately such questions arise as: Why idle-voluntarily or otherwise? Where idle-in one fixed spot or wherever one's wanderings may lead?

\section{The Wanderer or Transient}

If the purpose of early vagrancy legislation was labor immobility and concomitant wage-fixing, the purpose of these laws at a later date was protection of the community against strangers-for fear of their predatory habits, their apparent differences in modes of conduct, and the possibility of their becommg public charges. Similar concerns appear to affect the welfare system's indifference to the transient of today. Failure to provide mcome for modern "wanderers" is most apparent in the prerequisites of durational residence which characterize state public assistance laws. ${ }^{42}$ These requirements are permitted under the federally-aided categories despite the premium placed in our twentieth-century economy on labor mobihity. Grant-in-aid programs, with two notable exceptions, permit imposition of durational requirements. States, in turn, avail themselves

42 Characteristics of State Plans passin; Characteristics of GA passim; Mandelker, The Settlement Requirement in General Assistance (pt. 1), 1955 WASH. U.L.Q. 355, (pt. 2), 1956 WASH. UI.Q. 21. 
of the option. ${ }^{43}$ In general assistance, furthermore, the exclusively statecontrolled standards have produced even higher residence periods than are common in the federal-state categories. ${ }^{44}$

Insistence on durational periods of residence makes itself felt among the needy not only by persons legitimately characterized as "transient" but by those who by any other test would be regarded as firmly settled in a community. ${ }^{45}$ How can we, under contemporary living conditions, look on a resident of three years as transient? In seventeenth-century America obstacles to travel and establishment of a means of livelihood may have justified so regarding the newcomer. Fear of the possibility of his dependency operated to exclude him from entry into communities unless guarantees of "keeping the parish free" could be extended. ${ }^{46}$ No such promises are exacted or tolerable at present. Yet the tension between welcoming the stranger and resisting responsibility for his dependency persists, with painful results in some cases.

The wanderer, as a result, is often not an object of organized public charity, for lack of ability to meet a crucial test of entitlement-residence.

43 With but two exceptions the categorical aid laws permit state restrictions of eligibility based on length of residence. See 42 U.S.C. $\$ \S 302(\mathrm{~b})(2)(A), 1202$ (b)(1), 1352(b) (1), 1382(b) (1) (A) (1964) (OAA, AB, APTD, combined; not to exclude one who has resided therein for five out of the last nine years); see also 42 U.S.C. $\$ 602$ (b) (AFDC, one year per child or parent). The two exceptions are, significantly, medical vendor payment programs. See 42 U.S.C. $\$ \$ 302$ (b) (2) (B) (1964), 1396a(b) (3) (Supp. I, 1965) (MAA and AMT) ("state plan shall not contain any residence requirement which excludes any individual who resides in the State."); $c f$. BUREAU of FAMIIY Services, U.S. DEp'T of Heatte, Educ. \& Welfare, Handbook of Public Assistance, pt. IV, § 3620: "Every individual should be held to live or reside somewhere; that is, he should not be adjudged to be without a residence."

44 See Characteristics of GA passim. A settlement requirement, as well as a durational period of state residence, is common. In some states, localities are authorized to set their own settlement standards. Acquisition of settlement may require proof of a period of residence within a county without receipt of public or private assistance. See Mandelker (pt. 2), supra note 42, at 25-33. Compare 13 \& 14 Car. 2, c. 12 (1662) (prohibiting acquisition of settlement by any person within forty days of his arrival if resident in a dwelling whose rental value was less than ten pounds a year). Marshall states that those affected by this law included "not only the old, the infirm, the helpless, and the infants, but also all those agricultural labourers who worked for, and were dependent on, their wages; it affected the great class of manual workers of every kind; it affected most of the smaller manufacturers, such as the spinners, the weavers, the dyers, and the shearers; it affected, too, the large class of small craftsmen .... In short, [it] . . . included the greater part of the lower working class under the designation of "The Poor.'" Marshati, The English Poor in the Eighteentr Century 2 (1926).

$45 \mathrm{~A}$ brief account of mobile groups in the population and services presently available to them is contained in Migrants, Transients, and Nonresidents, 15 ENcrctopedr of SOCIAI WORK 512-18 (1956). The impact of residence lestrictions is detailed in Simons, Services to Uprooted and Unsettled Families, in National Conference on Soctal WeLpare, The Soctal Welfare ForUM, 1962, at 169 (1962).

46 See 1 AbBott, Public Assistance 150-55 (1940). 
That he does not starve more often than he does is a tribute to private philanthropy and the "hardship" clauses in many general assistance statutes. Yet this solution smacks of $a d$ hoc and unpredictable resolutions to a common enough plight. It is not a thoughtful attempt to deal with an eminently predictable social problem-the existence among newcomers of a few sure to become dependent upon others to save themselves from destitution. What measures should be taken to wholly eliminate this group's problems is the subject of another inquiry. ${ }^{47}$ It is sufficient to say that suggestions abound.

\footnotetext{
47 How to define the problems which require social action is also beyond the scope of the present inquiry but it should be noted that the "rootless" are as heterogeneous a group as the poor, or those labeled vagrants, for that matter. Some transiency is attributable to the type of employment which the individual pursues, for example, migratory agricultural labor. Customarily this transient is accompamed by his entire family, for their earnings significantly inflate what he brings in and are indispensable to reaching even a subsistence standard of living.

Another type of person that residence requirements may hurt is the worker who moves, frequently with a family, to seek permanent employment in another locality. Whether previously employed or not, his mobility is generated by a desire for selfbetterment. It is the better-educated, more skilled, and younger members of the labor force who tend to move, and to areas of low unemployment. See U.S. DEP'T OF LABOR, Manfower Report of the Prestdent and a Report on Manpower Requirearents, ReSOURCES, UTIIIZATION, AND TRAINLNG 145-48, 271-76 (1965) [hereinafter cited as MANPOWER REPORT]. This profile of worker mobility runs counter to the belief that people move to receive public assistance.

Yet another type of "transient" is the solitary drifter. He may move from one locality to another, taking employment from time to time, and he is often caught up in the law enforcement net as a vagrant. See generally Foote, supra note 3 . By definition he is a faceless member of society and his numbers can only be approximated from the contacts with private and public charities and a count of police blotters. This unan is not uncommonly confused with the residents of Skid Row, yet it is false to conclude that the inhabitants of such metropolitan areas are transients in any legally important sense. With respect to entitlement for assistance, for example, the significant facts are residence and/or settlement in geographically defined areas. The Skid Row resident is often a longtime inhabitant of that area who, if transient at all, moves within the area without jeopardizing residence or settlement. See, e.g., Migration and Mobility, in Tenants Relocation Bureav, Crry of Chicago, The Honrexess Man on Smot Row 38-39, 100-01, Table X (1961) (56\% of the men were residents on Skid Row for one year or more, $29 \%$ for five years or more; about $70 \%$ were in Chicago continuously for twelve months prior to the time of interview).

By contrast, note that the study of migration of workers reveals that one out of fifteen persons inoves from one county to another each year and about half the migrating group (or one out of thirty persons) move to another state. MAanpower Report 147, 271. The unemployed, many of whom are presumably poor, form a substantial proportion of the workers who migrate (10\% of the employed and $37 \%$ of the unemployed inigrants gave as their reason for migrating "to look for work." See MANTPOWER REPORT 271, Table J-2.) Furthermore, the unemployment rates among migrants exceed the rates for nonmigrants. Id. at 150 , Table 25 . Nonetheless, unemployed workers who migrate tend to have lower rates of unemployment than do the unemployed who stay put, id. at 149 , Chart 28 , a fact which becomes readily understandable if we look at the more desirable characteristics (age, race, occupation, education) of migrants as compared to nonmigrants,
} 
But the point stressed here is that public assistance laws make no substantial effort to resolve the economic problems of transients and persons with short periods of residence. The one substantial exception to this indictment of American efforts occurred in the 1930's when, under the first Roosevelt administration, measures of relief for the unsettled were introduced. ${ }^{48}$ From 1933 to 1935, the Federal Emergency Relief Administration aided the needy without regard to residence or settlement through its Transients Bureau, a federally administered and funded operation, and through state programs to which federal funds contributed a high though variable proportion of total expenditures. ${ }^{49}$

The experiment ground to a halt with passage of the Social Security Act. Creating a pattern of categorical assistances for presumed unemployables, the act established maximal periods of residence that state plans could adopt to receive federal matching. ${ }^{50}$ The pattern remains unaltered to date with the exception of the recently added medical care programs. ${ }^{.1}$ Thus the newcomer is precluded from assistance absent a showing of the one or three or five years that happens to be demanded, however well integrated into community life lie has become. Federal policy, by which the poorer states now receive up to eighty per cent federal matching under the categories, has tolerated durational periods where leverage for improvement exists. Not surprising, then, is the apphication of stiffer conditions in the wholly state and state-local program of general assistance. The vagrant-"wanderer" continues to pay a price for his mobility.

and, further, consider that areas of migration loss tend to be economically deprived according to several criteria. Id. at 151-54. Because, however, "migration is by no means a fully effective mechanism for bringing workers to jobs," id. at 158, the Manpower Report recommends a variety of measures to assure smoother matching of workers to jobs, id. at 158-75. Voices in other quarters have recommended improvements in existing programs to support the migrant and his family while the search for employment goes on. See, e.g., Simons, Social Services for the Mobile Poor in Urban Areas, in National Conference on Soctat Wetfare, Soctat Work Practice 162 (1965).

$48 \mathrm{~A}$ beginning at federally-funded relief had been made in the Hoover Administration by authorizing the Reconstruction Finance Corporation to lend funds to the states for relief and work relief. Emergency Relief and Construction Act of 1932, ch. 520, § 1, 47 Stat. 709. Payment on these loans was waived in 1934, Act of June 18, 1934, ch. 586, § 14, 48 Stat. 996. See generally The Long History of the Movement Toward Federal Aid for Social Welfare, in 1 AbBotr, Public Assistance 645-90 (1940).

49 Federal Emergency Rehef Act of 1933, ch. 30, 48 Stat. 55. The principal feature of FERA was the creation, in § 3, of a Federal Emergency Relief Administration, all the powers of which were to be exercised by a Federal Emergency Relief Administrator. Section 4 provided grants to the states for relief of need of persons and their dependents, whether resident, transient, or homeless. The problems of transients and nonresidents up to the micl-30's are illustrated in 1 Аввотт, op. cit. supra note 48, at 176-79, 283-345. See also BROWN, PuBLTC REIIEF: 1929-1939, at 259-63 (1940).

50 E.g., 49 Stat. 627 , as amended, 42 U.S.C. $\$ 602$ (b) (1964).

5176 Stat. 200 (1962), 42 U.S.C. \& 1382 (b)(2)(B) (1964); 79 Stat. 348, 42 U.S.C. $\S 1396 \mathrm{a}$ (b) (Supp. I, 1965). 


\section{2. "Idle and Without Visible Means of Support"}

(a) Introductory Comments.-Who shall be considered idle? In England the footloose laborer, described above, was often labeled idle whether or not he sought employment. At present it seems unlikely that a man actively looking for work would be treated as vagrant but occasionally examples are furnished that suggest otherwise. ${ }^{\mathbf{5}}$ Furthermore, the person who works intermittently in order to support extended periods of idleness at a subsistence level may be outwardly indistinguishable from one who is chromically idle.

For the criminal law the central question is whether idleness itself should be circumscribed.$^{53}$ For welfare law, particularly public assistance and unemployment insurance, the issue is different: It is whether, given the existence of income need, idle persons receiving grants or benefits may be asked to conform to standards of conduct related to work and self-improvement. As might be expected, income maintenance programs reflect important distinctions on this point arising out of popular views as to the employability of the various groups for whom income support is provided. A more lenient attitude is held, quite understandably, toward persons who are involuntarily rather than voluntarily idle.

Now the initial observation to be made is banal but important: that in practice, identification of the involuntarily idle presents far greater difficulties than a theoretical formulation might lead one to suspect. This is so, in part, because there exist on any day of the year unfilled jobs, some of which are available in theory to those currently out of work.

From the welfare perspective the direction of modern laws is toward identifying circumstances under which certain persons shall be deemed unemployable so far as entitlement to benefits is concerned. Examples of this approach exist in social welfare programs which establish tests of unemployability or of genuine retirement from the labor market. Thus a finding of disability deemed to be permanent, hence to preclude employment, is necessary under the federally-aided assistance program, Aid to the Permanently and Totally Disabled (APTD)..$^{54}$ Another example, this from social insurance, is the requirement of registration at an employment service office as a prerequisite to receipt of unemployment

E2 See Foote, supra note 3 , at 620 .

53 On the legality of proscribing sheer idleness, see discussion in Lacey, supra note 3 , at 1220 . Perkins, supra note 24 , at 238 , claims that "the concept of idleness per se as a crime had disappeared before it had an opportumity to be molded into the common law"; in his view it is idleness in combination with wandering, looseness, disorderly conduct, or absence of visible support that gives rise to punishable vagrancy. Id. at 239-44.

5464 Stat. 555 (1950), as amended, 42 U.S.C. \$§ 1351-55 (1964), as amended, 42 U.S.C. $\$ \$ 1352-55$ (Supp. I, 1965). 
compensation. It is coupled with a requirement to accept employment under specified conditions and, in many states, to actively seek work. ${ }^{56}$

By contrast, for receipt of Old-Age Insurance, retirement from the labor market rather than individually-determined unemployability is a test of entitlement. ${ }^{56}$ The presumptive unemployability of persons over sixty-five, reinforced by the retirement test, affords a method of balancing the desires to provide income as a matter of right to the aged and at the same time to limit the financial drain on the system by reducing benefits to those whose current earnings demonstrate a substantial degree of participation in the labor market. Note, however, that neither proof of unemployability nor proof of need are required for receipt of OldAge benefits; the test is measured by dollars of previously earned income.

What of the able-bodied unemployed, neither covered by insurance nor presumed unemployable? Only public assistance affords such persons the possibility of income maintenance and only under certain circumstances. Here the hand of poor law history is felt with the result, in tenBroek's words, that "idleness [which] in the rich has always been envied ... in the poor . . . is as socially reprehensible as ever."167

While critical attitudes toward the idle poor have long characterized poor relief, they became an especially important determinant of policy

55 See Comparison of State Ungaployment Insurance Laws, op. cit. supra note 40, at 47-87. See generally AltMan, Avamabmity FOR WORK (1950); BuRNs, op. cit. supra note 31 , at $70-79$. The similarities between the available-for-work test of unemployment compensation and compulsory work relief administered by poor law (now public assistance) officials are discussed in Mandelker, Refissals to Work and Union Objectives in the Administration of Taft-Hartley and Unemployment Compensation, 44 CORNETI L.Q. 477 (1959). Mandelker further notes that "no judicial interpretation of these [general assistance work-requirement] statutes has been found, but the available evidence indicates that the work refusal requirement in poor relicf is administered in torms of minimizing the relief load, without much consideration of individual preferences. This is so in spite of a study during the depression of the 1930's, indicating that only about $3 \%$ of the reported refusals of relief applicants to accept jobs were unjustified. The explanation lies in the nature of the program. Poor relief grants aim at the guarantee of aid at a subsistence level; higher standards cannot be expected in the administration of the work refusal requirement." Id. at 482 ; see note 85 infra and accompanying text.

5649 Stat. 623 (1935), as amended, 42 U.S.C. \$ 403 (f) (1964), as amended, 42 U.S.C. $\S 403$ (f) (Supp. I, 1965). Effective as of taxable years after December 31, 1965, retired beneficiaries may earn up to 150 dollars a month or 1800 dollars a year without loss of benefit. If earnings exceed 1800 dollars, 1 dollar in benefits will be withheld for each 2 dollars in earnings up to 3,000 dollars and for each 1 dollar of eamings thereafter. The retirement test is inapplicable to individuals who have reached age seventy-two. See generally Cohen, Retrremrent Potictes under Social Security (1957); Myers, Earmings Test under Old-Age, Survivors, and Disability Insurance, Social Security Bull., May 1964, p. 3 .

57 tenBroek, 17 Stan. L. REv. 675. 
in 1834 with enactment of the new Poor $\mathrm{Law}^{58}$ hard on the heels of the Speenhamland fiasco.59 Previous experimentation with workhouses and public works culminated in the adoption of the principle of less eligibility as the guideline to the level of public support, with the imposition of the workhouse test as the administrative technique for implementing it. Thereafter, the standard of living on relief was to be lower than that of the lowest paid labourer and available only in the form of indoor (workhouse) relief. ${ }^{60}$

Iniquities of this system liave been regaled at length, no more powerfully perliaps than by Dickens. ${ }^{61}$ Intended to be hygienic and corrective, the workhouses degenerated into places of sickness, corruption, and the

584 \& 5 Will. 4, c. 76 (1834). For evaluations of the new Poor Law of 1834, see generally de ScHWEINTT2, ENGLAND's Road to Soctar Security 128-39 (1943); WebB, op. cit. supra note 13 , at $56-102$.

50 The justices of the peace, meeting in Speenhamland in 1795, set a scale to relieve indigent families and supplement laborers' earnings which fell beneath the scale. By the time the Royal Commission on the Poor Laws was appointed in 1832, there was widespread opposition in England to this method of income maintenance on the ground that it pauperized the laboring class. See generally DE SCHWEINITZ, op. cit. supra note 58, at 69-78 (1943); Polany, The Great Transformation 77-85 (Beacon Paperback ed. 1957 ).

60 Chadwick's biographer, Finer, credits him with major responsibility for the principles underlying the new Poor Law and demonstrates Chadwick's debt to Bentham who introduced the principles of lenity, economy, and less-eligibility into discussion of penal reform. See FINER, LIFE AND TTMIES of SIR EDwIN CHADwICR 39-49, 69-95 (1952).

Lenity laid down the rule that health be protected, wlich Chadwick interpreted to require proper ventilation, hygienic standards, and hospital care. Economy called for strict disciphnary measures in enforcing work, contracting from the public for supplies, and dull, unpalatable, but unlimited food. Less-eligibility is worth parallel quotation:

BENTHAMI

The ordinary condition of a convict

Saving the regard due to life, health, and bodily ease ought not

Be made more eligible than that of

The Poorest class of subjects living in a state of mnocence and biberty.
THe POOR LAW REgort

His [the pauper's] situation on the whole shall not

be inade really or apparently so eligible as the situation of the independent labourer of the lowest class.

Id. at 75, quoting Benthant, Panapticon 122-23 (Works, Bowering ed. vol. iv) and His

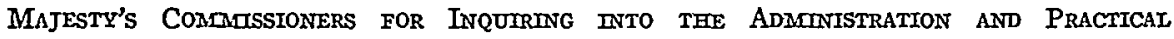
Operation of the PoOr Laws, Report 228 (1834).

${ }^{61}$ Aside from the well-known indictment in Oliver Twist (1838), Dickens elsewhere castigated the operators of workhouses, Poor Law officials generally, and private benefactors whose zealous espousal of foreign causes blinded them to evils close at hand. See, e.g., Our Mutuat Friend (1865), and Bleak House (1835). It seems likely that he was as accurate in describing the weaknesses of the contemporary welfare system as in his strictures against the legal system. No less an authority than Sir William Holdsworth vouches for Dicken's perceptiveness and factual precision in the latter respect. HorDsworTH, Dickens as a Legat Histortan (1929). 
indiscriminate herding together of the ill, aged, insane, criminal, and youthful types. More important from my standpoint in this inquiry, poor relief administration in the nineteenth century revealed an overemphasis on the able-bodied with consequent distortion of methods applied to other dependent classes. ${ }^{62}$ Moreover, policy toward the ablebodied failed to discriminate as to the circumstances preventing employment or giving rise to need. The simple assumption was that the able-bodied were voluntarily idle and policy must provide an effective deterrent to their reliance on public support. The 1834 deterrent was the workhouse. What is its modern counterpart?

(b) Conditions Relating to Employment in Current Income Maintenance Programs.-The intertwining of idleness as a vagrancy offense and of poor relief measures applied to the idle-that is, the unemployedis visible in English and American history. It remains to discover whether the punitive overtones of vagrancy and the new poor law resound in the modern welfare system. At the outset, let it be said that the language of repression and of penal goals has been discarded for newer concepts phrased in terms of work incentive and training or job skill upgrading. We turn to specific programs to interpret the new vocabulary.

(i) General Assistance.-In the first place, the able-bodied male, even if fulfilling residence or settlement requirements, is not, in many states, entitled to any income maintenance whatsoever ${ }^{63}$ Furthermore, a distinction must be drawn between states which permit aid for the totally unemployed and those which also extend it to the underemployed. Within some states making general assistance available to unemployed men, particular localities have the power to determine whether aid will be extended. Beyond this, it is difficult to generalize. Being subject to no federal control, general assistance programs vary greatly, and competent reports on their administration appear sporadically and are based in

62 The Webbs estimate that in 1833 able-bodied men on relief totalled about 100,000 out of a grand total of 700,000 in workhouses or receiving outdoor relief. WEBB \& WEBB, Engeish Locat Governament: Englise Poor Law flistory, Part H: The Last HunDRED YEARS $88 \mathrm{n} .1$ (1929). On the absence of statistics on pauperism to support the conclusions and recommendations of the Royal Commission of 1832-34, see id. at 82-90.

In 1966, if all general assistance families are counted as having one able-bodied unemployed adult, and if all AFDC families are (quite unreasonably, of course) treated likewise, the estimate is approximately $1,300,000$ able-bodied dependent poor. If, in addition, all recipients of unemployment insurance are added, the total increases to slightly under 2,300,000. Social Security Bull., Jan. 1966, pp. 54, 55. At its largest, however, this sum is a minor proportion of the "unemployable" indigent and presumed-to-be needy groups aided through assistance (6.5 million, excluding AFDC and general assistance heads, counted above as "able-bodied") and social insurance ( 25.5 million, excluding beneficiaries of railroad retirement, federal civil service, temporary disability, and all types of unemployment insurance). Id. at 46,55 .

${ }^{63}$ See note 38 supra. 
large part on estimates. The isolated bits of testimony available form a picture of discretionary administration of income provision under which conditions of the grant are markedly less favorable than those under the categorical programs. ${ }^{64}$ It seems reasonable to assume, then, that the idle person receiving general assistance has frequently been subjected to experiences similar to those awaiting the committed vagrant -so many days at hard labor, albeit undertaken outside of jail and by one who is able to go home at night. ${ }^{65}$

(ii) $A F D C$-UP.-Eighteen states offer a better solution through AFDC-UP, the addition to AFDC which permits federal matching of grants to needy families contaiming an unemployed parent. ${ }^{66}$ Heretofore the policy underlying all the federal categories limited grants to persons deemed unemployable. Under AFDC, "dependent child," as earlier defined, meant children whose need for financial aid arose out of illegitimacy, or the death, desertion, disability, or continued absence from the home of parent or parents, and who were receiving care from one of several enumerated categories of relatives. ${ }^{67}$ In 1961 the program was enlarged to allow states to include children in families with unemployed parents in the home. ${ }^{68}$ In 1962 the unemployed parent himself was added, further imcreasing the amount the federal government would match. ${ }^{69}$

At the same time that presence of the unemployed parent was removed as a bar to receipt of AFDC, Congress imposed conditions designed to stimulate the employment or enhance the employability of that parent-

\footnotetext{
04 See, e.g., Breul, Survey of the Administration of General Assistance in Bloom Township, Illinois, Dec. 1963.

${ }_{65}^{65}$ The well-publicized case of People v. LaFountain, 21 App. Div. 2d 719, 249 N.Y.S. 2d 744 (1964), is instructive on this point. See generally Mandell, The Crime of Poverty, Social Work, Jan. 1966, p. 11; cf., Mass. ANN. LAws ch. 117, § 20 (1958) ("The board of public welfare ... may and in cases of tramps and vagrants shall require any person applying for and receiving food or lodging to perform, if plysically able, a reasonable amount of labor in return therefor, and may detain him for no more than twenty hours . . . until the labor . . . las been performed."). (Repealed, Mass. Acts 1965, ch. 523, § 4.)

${ }^{66}$ At the time of preparation of this article the states were: California, Connecticut, Delaware, Hawaii, Illinois, Kansas, Maryland, Massachusetts, Michigan, New York, Ohio, Oklahoma, Oregon, Pennsylvania, Rhode Island, Utah, Washington, West Virginia. Welfare in Review, Dec. 1965, p. 39.

6749 Stat. 629 (1935), as amended, 42 U.S.C. $\S 606$ (a) (Supp. I, 1965). Relatives specified include parents, grandparents, siblings, stepparents, step-siblings, uncles, aunts, first cousins, and nephews and meces. This listing of relatives is subtantially as enacted in 1935. Note, however, that the prototype for AFDC, Mother's Pension laws, tended to be more restrictive in describing the eligible caretaker class and the conditions of parental deprivation giving rise to eligibility in the first instance. See U.S. Soctax SEcurrTY Bn., Soctar SecurItY IN AMERTCA 233-37 (1937).

. 6875 Stat. 75 (1961), as amended, 42 U.S.C. § 607 (1964).

6976 Stat. 190 (1962), 42 U.S.C. \& 606(b)(1) (1964). See generally Cohen \& Ball, The Public Welfare Amendments of 1962, 20 PuBLIC WeLfare 191 (1962).
} 
that is, to eliminate his idleness and lack of means of support. Thus every state seeking to avail itself of AFDC-UP must include, in its state plan, provisions assuring the welfare department's cooperation with public employment offices in finding employment for the parent, termination of aid to families "if, and for as long as, the unemployed parent refuses without good cause to accept employment," and use of existing vocational educational facilities for retrainmg programs. Receipt of aid is contingent upon parental participation in retraining when the caseworker recommends it. $^{\text {70 }}$

The public policy seems clear enough: Congress, upon making unemployment ground for receipt of aid under the AFDC program, concluded that the states should step up efforts to reduce unemployment. ${ }^{71}$ This policy manifests the public preference for employment over relief, not only for its effect on relief expenditures, but equally for the personal satisfactions gained by formerly-dependent individuals.

Section 407 of the AFDC title ${ }^{72}$ seeks to accomplish this result. States which fail to meet employment and training provisions receive no federal matching. Note that these new provisions relate entirely to the conditions to be imposed, under the state plan, upon the parent; it is his uncooperativeness, in the absence of "good cause," which triggers termination of the grant to himself, to any other eligible relative, and to the child or children who are receiving aid.

A later provision tackles the problem of parental unemployment from a different aspect. Section 409, enacted in 1962 as one of the so-called "service amendments," makes possible federal matching of "payments for work performed ... for the State agency or any other public agency under a program .... administered by or under the supervision of such State Agency ...." The concept is broadly conceived. It comprehends

\footnotetext{
70 These requirements are stated as additional state plan requirements, 75 Stat. 75 (1961), as amended, 42 U.S.C. $\$ 607$ (1964). For federal matching the states must show that the specified provisions have been met. Note, however, that no federal funds were made available at this time (1961) to support the states in the development of work referral or retraining services. See text accompanying notes 72,73 infra.

$71 \mathrm{Cf}$. the statement accompanying the 1962 amendments, 76 Stat. 186 (1962), as amended, 42 U.S.C. \$ 609 (a) (1964), in the Senate Report: "The committee recognizes that some provision must be made to deal with the problem of providing useful work for the unemployment parent. . . The committee beheves that states should be permitted, if they wish, to have commumity work and training programs for employable people, and provides for such a program as a part of the aid to dependent children program. Under the provisions of the bill, states that wish to have such programs could do so if they fulfill certain safeguarding provisions. If a state plan is approved, assistance could be denied if the individual refuses without good cause to take the work offered." S. REP. No. 1589, 87th Cong., 2d Sess. 11 (1962).

7275 Stat. 75 (1961), as amended, 42 U.S.C. \$ 607 (1964).

7376 Stat. 186 (1962), as amended, 42 U.S.C. $\$ 609$ (a) (1964).
} 
"community work and training programs of a constructive nature" for the avowed purpose of encouraging "the conservation of work skills and the development of new skills for individuals who have attained the age of 18 and are receiving" AFDC. ${ }^{74}$

Despite the use of new language, with the emphasis on "conservation" or "development" of work skills, there is a suspicion that Congress feared the possibility of confusion with old-fashioned work relief. ${ }^{75} \mathrm{~A}$ desire to head off abuses previously associated with work relief may be read into the insertion of state plan requirements of a protective nature. Section 409 (a) adumbrates a host of conditions related to the recipient's personal and career protection. Health and safety standards inust be observed; rates of pay for work performed in community work and training must be those prevailing in the community; work must be useful and displace no regular workers. Further, state plans must provide for mandatory budgeting of work expenses, affording opportunities to seek employment and any other training available, coverage under workmen's compensation, and recognition of "good cause" as a ground for refusal to perform work requested. An additional safeguard, especially pertinent to mothers, is the insistence on "appropriate arrangements for the care and protection of the child during the absence from the home of any such relative performing work under such program in order to assure that sucli absence and work will not be inimical to the welfare of the child." 78

By these ainendments, conditions relative to work relief, acceptance of employment, and assigument to training projects have been inserted into a federal program of public assistance for the first time since the 1940 's. In conception they resemble earlier methods of conditional support to able-bodied paupers, notwithstanding obvious efforts to install a "new look" into efforts to deter malingerers and the apathetic from ready reliance on a public source of income. But can anything be said against sucl a commendable purpose? And what do the burgeoning programs of work relief and training have to do with the concept of vagrancy?

The answers to these questions appear to turn on what the essential purposes of the new requirements are. To the extent that repressive

74 Ibid. While the community work and training programs are not limited to states which adopt AFDC-UP, in fact the ten states presently administering such programs are within the group of eighteen jurisdictions which lave AFDC-UP. See Welfare in Review, Feb. 1966, p. 29.

75 See S. REP. No. 1589, op. cit. supra note 71 , at 11: "The bill contains several safeguards that will assure that the projects will be useful and also that the individual worker will be protected against possible abuse or exploitation."

7076 Stat. 187 (1962), 42 U.S.C. § 609(a) (4) (1964). 
policies motivate their enactment and administration, they may fairly be compared to work relief, or what is more accurately called work-forrelief. ${ }^{77}$ In this sense they closely resemble the vagrancy offense in that their objective is the punishment of idleness, in this instance througll presenting a clioice between privation or work or training, no matter how uncongenial. Ascertaining legislative intent and accurately characterizing administrative practice are far from siniple tasks. It is probable, for one thing, that legislators and administrators alike are motivated not only by deterrent policies ${ }^{78}$ but equally by policies conceived as genuinely therapeutic. ${ }^{79}$ In the last analysis, we can best interpret the goals of community work and training in the light of past experience with such undertakings and the present available alternatives.

The overall ain of the public policy under consideration is employnient. For marginal members of the labor force attainnent of this goal is thought to require indoctrination in work habits, training geared to

77 A summary and evaluation of work relief in the United States is contained in Feder, UNeacployment ReLtef in Pertods of Depression 352-53 (1936). See also

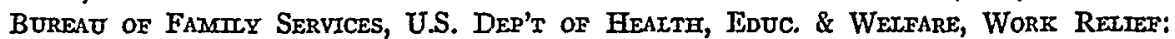
A Current Look (Public Assistance Rep. No. 52, 1962); Corcoro, Koprovitz \& KurTz, EMtergency Work ReLIEe (1932); Howard, THe WPA aNd FederaI ReLtef Poltcy (1943); Macmahon, Mirleti \& Ogden, The adncinistration of Federal Work Rettep (1941). See generally FEDER, op. cit. supra, at 31-34, 67-70, 123-25, 168-85, 214-17, 278-76. The principal objections to work relief have centered on its use as a work test, regarded as wholly unsuitable in severe depressions, the inappropriateness of work provided in terms of physical demand and needs of the economy, competition with industry, and its high cost relative to direct relief. Critics have also questioned the wisdom of limiting wages received as work relief to the amount of budgeted need to which the recipicnt is entitled and some have urged that earnings from work relief exceed direct relief (yet be low enough so as not to reduce the incentive to seek employment in the private sector). E.g., BENNETT, UNEMPIOXMENT AND REIIEF 176-79 (1955). A necessary distinction between work relief and public works is usually noted; the equally useful distinction is less often drawn between work relief (work of tangible value to the commumity designed to maintain morale and skills of employables; Works Progress Administration progranus furnislı an example) and work-for-relief (work for purposes of establishing eligibility; a work test; further distinguishable from work relief by limiting work to that noeded to amount of relief grant in contrast to WPA policy of paying flat. weekly wages). Id. at 123. The current community work and training programs may be said to combine these different objectives.

78 However distant the evils of Speenhanland, see Porany, TaE Great TransFORMation 77-85 (Beacon Paperback ed. 1957), may seen to be, twentieth-century commentators also have feared the pauperizing effects of indefinite welfare support. Sec Lampnian, Approaches to the Reduction of Poverty, reprinted in POVERTY IN AMERICA 418 (Ferman, Kornbluh \& Haber eds. 1965); Editorial, N.Y. Times, Feb. 4, 1966, p. 30, col. 1. Compare Schwartz, A Way to End the Means Test, Socinl Work, July 1964, p. 3, at 8-10. See generally Hopkns, Spending to SAve 108-25, 160-78 (1936).

79 Martz \& Huyck, From Work Relief to Rehabilitation Through Work and Training, in U.S. Def'T of Healte, Educ. \& Welfare, New Difections on Health, Education, aNd Wextare 250, 254-57 (1963); Truelson, One-by-One Approach to People's Problemis, 23 Public Welfare 116 (1965). See also S. Rep. No. 1589, op. cit. supra note 71, at 11. 
specific jobs and, sometimes, social services designed to heighten the motivation to move into the mainstream of economic and social life. ${ }^{80}$ The underlying assumptions, of course, are that jobs will be widely available and that in a society based on a work ethic the good of all, and especially of the dependent poor themselves, will be furthered by diminishing the ranks of the unemployed.

Community work and training programs appear to move in the direction of increasing employment opportunity. Yet certain inconsistencies in supporting pohicies can be identified. Some are inherent in the statutory scheme. For instance, work must be useful and paid for at prevailing rates. ${ }^{81}$ Its availability, however, hinges on its not being performed under existing labor market conditions. Thus one recommended form of work, euphemistically entitled training, is clearing brush on secondary roads. ${ }^{82}$ This, it is submitted, may be socially useful, but its immediate value to the recipient whose job opportunities today lie largely in industry or service occupations can be seriously challenged.

80 Levine, Seeking Out Employment Opportzmities, Employment Service Rev., Dec. 1965, p. 1.

8176 Stat. 186 (1962), 42 U.S.C. $\$ \S 609$ (a) (1)(B), (C) (1964).

82 See Guidelines for Programming, in BuREaU of Family Services, U.S. DEP'T OF Heattr, Educ. \& Welfare, Handbook of Publtc Assistance Administration, SuppleMENT B, § B-2130.9 (in reference to Title V of the Economic Opportunity Act, 78 Stat. 527, 42 U.S.C. $\$ \S 2921-23$ (1964), as amended, 42 U.S.C. $\$ \S 2922,2923$ (Supp. I, 1965)): "With the Administration's strong interest in beautification, welfare agencies are encouraged to include work experience umits in this area in their Title $\mathrm{V}$ projects. Roadside beautification, including removal or fencing off of junk car 'graveyards,' would be particularly appropriate along secondary roads beeause of their proximity to the homes of Title $V$ participants. State and local highway departments would be sponsors for such projects. In addition, beautification work may be done for park or recreation departments, schools, forestry agencies, etc. Through constructive work experience in beautification, participants may learn, along with good work babits, skills in grading land, planting trees, lawns and shrubbery; and conservation work and some construction (roadside rest stops, camp sites). This work experience must adhere to the requirements governing Title $V$ projects ...."

A study of work relief conducted by the Bureau of Family Services in 1961 revealed that the majority of work projects then in operation were of a maintenance or custodial character: "These conclusions about work relief by the Bureau of Family Services are based on observations of the program as currently conducted. Some of them confirm what was learned by public welfare people in the 1930's and recorded in their experiences.

1. Properly administered work relief projects can help recipients become better able to compete for jobs in the regular labor market. But according to the inquiry, few projects are doing so. The Bureau believes that this is because many welfare agencies were not equipped to classify recipients according to their work capacities and did not offer enough different kinds of work. . .

4. The problem that earher work relief administrators faced in selecting projects still exists: Projects that are useful to the community are inore likely to interfere with regular employment, and hence are difficult to justify as work relief."

WORK RELIEF, op. cit. supra note 77, at 15. 
In addition, if either work or training have real value to the recipient, why is he not rewarded beyond the amount of his grant? ${ }^{83}$ Why does his participation in work or training cease when the grant has been earned, unless of course he chooses to "volunteer"? Further, we may ask, is the type of training, for training receives the emphasis rather than work in a number of states, soundly geared to the employment market? ${ }^{84}$ Is a welfare administration equipped to operate programs of training which will coincide with labor market demands?

Another source of difficulty is the opportunity for discretionary administrative practices under the work and training programs. So long as the recipient's participation is prerequisite to receipt of assistance, his fate lies in the hands of the staff. It is the caseworker who decides on referral for work or training, and the caseworker or a farther-removed staff inember who determines whether refusal to participate is based on "good cause." 85

In all fairness, two observations should be made. One is that work and training for the recipient of assistance, though theoretically available in other departments of government, is in fact often unavailable outside the

83 "In most of the agencies visited, work relief recipients worked about two weeks out of the month." Id. at 11. See also Moreland Coma's, Report on Public Welfare IN THE STATE OF NEW YORK 61-62 (1963).

84 Training receives verbal emphasis today as compared to 1961 and under the new title V training projects funded by OEO training programs are rapidly expanding. Questions respecting the suitability of the training programs for individual recipients and the considerable discretionary authority vested in the caseworker have been raised, notwithstanding the general concurrence in training goals as appropriate replacenient of working-out-relief assignments. See address by Arnold Weber, Professor, Graduate School of Business, University of Chicago, The Role and Limits of National Manpower Policies, Eighteenth Annual Mecting of the Industrial Relations Research Association, Dec. 1965; Greenleigh Assoctates, Public Welfare: Poverty, Prevention or Perpetuation, A Study of the State Departarent of Public Assistance of the State of Washington 40 (1964) (reporting on small portions of recipients in job training and rehabilitation programs).

85 See, e.g., Greenleigh Assoctates, Report to Moretand Conmission on Weitare 51-55 (1962). It seems reasonable to predict that both caseworker and administrator initiating a particular training referral or training project will regard it as suitable. For an historical footnote, see Serota, The Myth of Work Refusals, in AMrrican Ass's Soctal Workers, This Bustness of REITEF 33 (1936). Consider refusal to perform "work" (to participate in work experience and training project activities) for good cause. title $V$ projects for AFDC recipients, see text accompanying notes 87-96 infra, must allow the good cause ground, 42 U.S.C. $\S 609$ (a)(1)(G) (1964), the objective being protection of recipients from unjustified termination of their grants. Criteria for judging the reasonableness of refusals inevitably elicit discretionary administration of such items as "obviously unsuitable work experience or training assignment," assignment to a job "that, combined with heavy home burdens, would make excessive demands," lack of child care, or "special needs of children." BUREAU OF FAMENY SERvices, op. cit. supra note 82, at $\S$ B-2463. Consider also: "[R]efusal to accept assigninent, to continue on a project, or to transfer to another assignment in the project, may indicate the need for counsching, medical care, psychiatric help or special social scrvices." Ibid. 
welfare department, thus forcing it into this business. ${ }^{86}$ Second, the problems alluded to above are not unique to public assistance. On the contrary, they have plagued administration of unemployment insurance, and because of many of the same underlying attitudes; unemployment must be a person's own fault, and only repressive measures will keep him from a life of dependency.

Nonetheless, the problems of administering work and training requirements, in my opinion, are most acute in AFDC and general assistance, the programs which attract the most inarticulate and socially-defective clientele by virtue of their residual nature. Within these two programs, evidence indicates that, at least to some extent, the attitudes whicli shape the implementation of the requirements arise from the same punitive instincts which liave maintained the crime of vagrancy.

(c) Demonstration Projects under EOA.-Closely related to the community work and training provisions of AFDC are the demonstration projects instituted in 1962 under section 1115 of the Social Security Act ${ }^{87}$ and further extended by title $V$ of the Economic Opportunity Act of $1964 .^{88}$ The purpose of this set of provisions is twofold: to enable states to experiment with new types of programs as demonstrations, thereby avoiding the customary federal requirement of state-wide availability of service; and to encourage projects designed to enliance employability or capacity for self-support. Whereas community work and training under AFDC is restricted to that class of recipients, the title $V$ projects are open to recipients under any of the categories and to persons likely to become recipients. As of November 11, 1965, 46,500 persons were enrolled in a total of 139 projects distributed over forty-two states and involving a wide range of training..$^{89}$

What proportion of the caseload of presumably able-bodied recipients of assistance is represented in the trainee caseload? The question cannot be answered. Only a poor estimate can be hazarded on the basis of inferences drawn from data on AFDC-UP. From November 1965 statistics on assistance programs, we find that 17,653 adult recipients were enrolled in community work and training under AFDC. ${ }^{90}$ As of this date 5,600

86 "The poor have been relatively neglected by the public employment services of Detroit and by other services which exist to counsel, train, and place in jobs the ablebodied or the disabled." Greenleigr Associates, Study of Services to Deal with Poverty In Detrort, Michigan 21-22 (1965). See also id. at 21-24, 62-76.

8776 Stat. 192 (1962), as amended, 42 U.S.C. $\$ 1315$ (Supp. I, 1965).

8878 Stat. 527, 42 U.S.C. \$\$ 2921-23 (1964), as amended, 42 U.S.C. \$§ 2922, 2923 (Supp. I, 1965).

89 Office of Special Services, U. S. Bureau of Family Services, Work Experience and Training Report to the Office of Economic Opportumity, Nov. 25, 1965.

o0 Bureau of Famity Services, U.S. Dep't of Healte, Educ. \& Werfare, Advance Release of Statistics on Public Assistance, Table 9 (Nov. 1965). 
enrollees in the title $V$ projects were AFDC adults drawn from community work and training programs. ${ }^{91}$ To state the facts negatively, 40,900 of the 46,500 total on title $V$ projects were not drawn from community work and training programs. The data should not be interpreted, however, to signify that AFDC adults are not being trained in the title $V$ projects. On the contrary it is more plausible to hypothesize that most trainees are drawn from AFDC, the program with the highest potential of employables, with a sizable enrollment in states which do not have AFDC-UP and hence no community work and training program. ${ }^{02}$

Two curious anomalies underlie any effort to advance a consistent interpretation of the purpose of title $V$ projects. One is the fact that compulsion exists for AFDC recipients; ${ }^{03}$ not so for recipients in other categories to whom enrollment in title $\mathrm{V}$ projects is offered. The other derives from the facts on enrollment; at this point a substantial proportion of trainees are females. One might expect a genuine employment opportunity program to reacl out for all unemployed males in an effort to restore them to the status of primary earner in the family. ${ }^{04}$ It is a

01 Note 89 supra.

82 Cf. Bureau of Fammy Services, op. cit. supra note 82, \& B-2123; Truelson, Helping Needy People Get Jobs and Hold Them, Welfare in Review, Nov. 1965, p. 14; see note 74 supra.

03 By incorporation, see 42 U.S.C. \& 2922 (Supp. I, 1965), referring to 42 U.S.C. \& 1315 (Supp. I, 1965) (demonstration projects), referring to title IV, AFDC.

94 See Truelson, supra note 92, at 15. Forty-four per cent of the title $V$ trainees nationwide are female. Ibid. Original plans for a title $\mathrm{V}$ project in Wayne County, Michigan called for training of 1700 AFDC-UP males, to be followed by training for about 1000 AFDC-UP mothers with children over fourteen. "The favorable employment market has resulted in a reduction ... in caseload . . reflected in the preponderance of ADC mothers in the projects even though priority is given to unemployed fathers as the law suggests ....

TITIE V PARTICIPANTS

\begin{tabular}{lccc}
\hline & Oct. 31, 1965 & & \\
& Men & Women & Total \\
\hline White & 306 & 245 & 551 \\
Non-White & 735 & $\overline{1318}$ & $\frac{2053}{2604}$ \\
Total & $\overline{1041}$ & 1563 & 2604 \\
\hline
\end{tabular}

Of the men, 714 were receiving work experience and training, 158 training only. For women the situation was reversed." Mich. Dep't Social Services, Work Experience Program, Nov. 65.

This seems to be in accord with stated federal policy. "The estimated participation in the title $V$ program is $2,110,000$ persons. This number includes $1,750,000$ part-time employed and unemployed heads of families and 220,000 AFDC mothers of the over 1 million AFDC families. Our immediate target is 350,000 needy, hardcore, unemployed persons including the 220,000 AFDC mothers I mentioned." Address by Andrew R. N. Truelson, 
status which, we have been told, critically affects the movement of Negro families out of poverty and into the relative affluence and stability of the middle class. ${ }^{95}$ A counterargument points to the rapid turnover of AFDC-UP families receiving aid because of parental unemployment. Such a high turnover, it is suggested, precludes extended traming efforts directed at male recipients. To this two responses may be offered: Comparisons of numbers of assistance recipients with numbers currently reported in training belies the assertion that no men exist to be trained. Furthermore, a dwindling number of prinary breadwinners for the

The Work Experience Program under Title $V$ of the Economic Opportunity Act 5, American Public Welfare Ass'n, National Biennial Round Table Conference, Dec. 3, 1965. Sinilarly, in the conmunity work and training programs supported under AFDC, the majority of trainees are apparently wonen. In sone states the relatively high proportion of women in training programs is a consequence of a tight employment market for men and a rapid turnover of AFDC-UP cases. In West Virginia, where all 8610 families receiving AFDC-UP are listed as having an adult participant in a comnunity work and training program, it is probable that the average length of an AFDC-UP case is considerably longer than other AFDC-UP states and/or the emphasis in administration is on work, not training. Welfare in Review, Dec. 1965, p. 39.

95 With respect to Negro males, the point has repeatedly been stressed that access to rewarding eniployment is essential not only to self-esteem but to family stability. See generally THE Negro AMrerican (Daedalus, pt. 1, Fall 1965; pt. 2, Winter 1966). The point would seein equally applicable to unemployed white males. Whereas Department of Labor statistics routinely classify MDTA trainees by both sex and race, data on the welfare-sponsored training programs so far published give only sex and types of training provided by project (not by trainees enrolled). Analysis and evaluation of the Title $\mathrm{V}$ and AFDC-UP training programs demand cross-classification by sex, race, and type of training provided to individual enrollees (the last-named will soon be available; personal coinmunication to the author from Andrew R. N. Truelson, Ass't Director, Special Services, Welfare Administration, dated Jan. 21, 1966). It would also be useful to have a breakdown by category of enrollees who are public assistance recipients. At this writing Title $\mathrm{V}$ project approval is restricted to projects serving categorical assistance recipients or "categorically related" persons (for example, parents of youngsters up to age twenty-one) notwithstanding legislative authorization to serve "other needy persons." See WeLFare admintstratoon, U.S. Dep't of Healte, Educ. \& Welfare, handbooz Transamtrai No. 73 (Dec. 21, 1965).

To be sure, restricting enrollment in training programs to men might set off a hue and cry about discrimination against wonen. Cf. Civil Rights Act of 1964, $\$$ 703(a)-(e), 42 U.S.C. $\$ \S 2000 \mathrm{e}-2$ (a) -(e) 1964. But it is not necessary to bar women from training programs altogether in order to give priority in design and inplementation of such programs to males of relatively young age who have recently assumed or nuay be expected to assune family responsibilities. As long as men fill the role of primary breadwinner in American society, aiding the disadvantaged among them to fill this role more successfully would appear to be sound national policy. In addition, it should be noted that the training programs for women nlay be perpetuating a well-recognized type of discrimination against women: training then for jobs which are low-paid and offer irregular enuployment and few fringe benefits. If, as is argued, these are jobs that men often will not take and wonien should not have to take, what do we make of welfare-sponsored policies which direct women to enroll in training programs leading to these jobs? See generally Peterson, Working Women, in The Woraan IN AMerica 671, 681-87 (Daedalus, Spring 1964). 
training programs should perhaps force a reevaluation of the whole effort. Further attention to this issue is given in a later section..$^{00}$

(d) Other Training Programs.-Welfare programs are neither the exclusive nor the primary setting for training efforts at the present. There are now several work and training programs outside the income maintenance programs. Some reflect new approaclies generated by apprehensions that automation has produced new labor market problems or the conviction that a new set of manpower policies is needed in the United States. ${ }^{\mathbf{7}}$ Other programs are extensions or modifications of earlier public efforts; an example is the Youth Conservation Corps within the Job Corps program of the Economic Opportunity Act of $1964 .^{98}$ Its lineage is traceable back to the depression program of the Civilian Conservation Corps. ${ }^{99}$

All of these programs secure enrollees voluntarily. Indeed, voluntary enrollment is essential since full coverage of target populations is neither intended nor feasible in the immediate future. The underlying goal is to provide training and education for able-bodied persons who are seen as particularly vulnerable to the risks of unemployment or intermittent, unrewarding employment. ${ }^{100}$ The hope is that the variety in types of programs and in enrollment techniques will attract members of these identified groups and produce the results desired. By December 1964, 340,000 trainees had been approved for training projects under the Manpower Development and Training Act whereas in the Neighborliood Youth Corps under the Economic Opportunity Act 308,000 training spaces had been allotted. ${ }^{101}$ By comparison, the numbers being trained under public assistance auspices look small. ${ }^{102}$

The social ills to be remedied by these particular programs are

06 See text commencing with footnote 119 infra.

97 E.g., the Manpower Development and Training Act of 1962, 76 Stat. 23, as amended, 42 U.S.C. \$\$ 2571-2620 (1964), as amended, 42 U.S.C. $\$ \S 2571-2620$ (Supp. I, 1965), and the Area Redevelopment Act, 75 Stat. 47 (1961), as amended, 42 U.S.C. $\$ \S ~ 2501-25$ (1964), as amended, 42 U.S.C. $\$ \S 2513,2514$ (repealed), 2525 (Supp. I, 1965).

08 Economic Opportumity Act of 1964, 78 Stat. 511, 42 U.S.C. $\$ 2720$ (Supp. I, 1965): "Within the Job Corps there is authorized a Youth Conservation Corps in which at any one time no less than 40 per centum of the male enrollees under this part shall be assigned to camps where their work activity is directed primarily toward conserving, developing, and managing the public natural resources of the Nation, and developing, managing, and protecting public recreational areas."

99 Civilian Conservation Corps Reforestation Relief Act, ch. 17, 48 Stat. 22 (1933).

100 These programs, in effect, permit rendering compensatory treatment to unemployed Negro youth and adults without so labelling the efforts. See Transcript, ConferENCE ON THE NEGro AMERICAN 288-99 (Daedalus, Winter 1966).

101 U.S. Buread of THE Budget, THE Budget of the United States Government FOR FISCAL YEAR ENDING 1967, App. 125 (1966).

102 See text accompanying notes 89-91 supra. 
essentially the same that AFDC seeks to eradicate through its work and training. But the approaches differ markedly. One has open enrollment, the other required participation. One heavily relies on "indigenous" leaders to hurdle the barriers of communication and make participation seem more meaningful and less formidable; the other is dominated (or so it has been claimed) by middle-class persons whose language and values set barriers between themselves and the client group. ${ }^{103}$

(e) Conclusion.-A review of various work and training programs designed for assistance recipents identifies features more readily explained as reflections of dislike of idleness than of the unique requirements of the population in the recipient status. The effectiveness of these various attacks on unemployment has yet to be measured in any systematic way. In light of the value placed on freedom of choice and dignity in our society, however, elements of compulsion in any welfare program ought to rest on a carefully justified necessity. To be required to do what is good for oneself is a far different approach to human ills than the assurance of aid to self-betterment. In general, our tendency has been to endorse the latter approach and to insist on closely reasoned explanations to support the former. The vagrancy concept, we may conclude, lies in the background of these compulsory programs.

\section{The Deserting Father: Is He a Welfare Vagrant?}

A common element of the vagrancy offense is desertion of a family with the consequence of their becoming public charges. ${ }^{104}$ It should be noted that desertion and nonsupport laws have always been applicable to parents, mainly fathers, who shirk their duties. Further, relatives' responsibility provisions have been available since $1597^{105}$ and have ap-

\footnotetext{
${ }^{103}$ Among useful items in a rapidly expanding literature on problems engendered by the middle-class bias of social workers and on indigenous leadership potential are: HUNTER, The Slumis: Challenge and Response 265-68 (1964); Silberman, Crisis in Black and WHITE 308-55 (1964); Brager, Organizing the Unaffiliated in a Low-Income Area, in Soctal Welfare Institutions 644 (Zald ed. 1965); Cloward \& Epstein, Private Social Welfare's Disengagement From the Poor, in id. at 623; Cohen, Social Work and the Culture of Poverty, in Mentad Health of the Poor 128 (Riesman, Cohen \& Pearl eds. 1964).

${ }^{104}$ First introduced as a vagrancy concept in 1744 , 17 Geo. 2, c. 5, it applied to one who deserted lis family if they became a charge on the parish. See Rex v. Hall, 3 Burr. 1636, 97 Eng. Rep. 1022 (K.B. 1765); Perkins, The Vagrancy Concepl, 9 Hastnos L.J. $237,246-47$ (1958). Lacey identifies ten states as including in the defimition of vagrant one who fails to support his family, without the further requirement of slowing that the family is a public charge. Lacey, Vagrancy and Other Crimes of Personal Condition, 66 HARv. L. Rev. 1203, 1209 (1953). A coinmon fate for him who refuses work relief or job offers appears to be a threat of referral for prosecution for nonsupport. See Mandell, The Crime of Poverty, Social Work, Jan. 1966, p. 11, at 12; Reich, Individual Rights and Social Welfare: The Emerging Social Issues, 74 YALE L.J. 1245, 1249 (1965).

10539 Eliz. 1, c. 3 (1597).
} 
plied to a wider circle of relatives than do the nonsupport provisions. Welfare statutes derived from the poor law have quite universally retained some form of relatives' responsibility, raising the most perplexing problems of policy. ${ }^{106}$ Until the 1952 amendment of the AFDC title for Notification of Law Enforcement Officers (NOLEO), ${ }^{107}$ the problems centered on discretionary application of responsibility provisions by public assistance workers. NOLEO brought additional elements of discretion and repression which reflect vagrancy concepts.

NOLEO is the product of public concern over mounting proportions of AFDC families whose eligibility arises from a parent's desertion. It requires notification to law enforcement officers of the furnisling of aid to families where a parent has abandoned or deserted; this duty has been reinforced in some states by requiring the child's custodian to file charges for child support. ${ }^{108}$ The net effect of NOLEO is to limit assistance agency discretion in determining what support action is reasonable in each case, particularly in states with a mandatory filing requirement.

NOLEO, then, highlights a conflict in values which has long persisted. ${ }^{109}$ On the one land, the public can be said to deserve protection from the burden of supporting families when the parents are able to. While parental support is usually forthcoming voluntarily, and increased amounts often follow from assistance agency interpretation of parental duties, ${ }^{110}$ inevitably cases appropriate for legal action will arise, even though their numbers be small. Recourse to legal action may buttress the sense of moral obligation and thus be important as a deterrent.

Opposing arguments stress the punitive consequences of federal-state reporting and state filing provisions. Insistence on pursuit of remedies may hamper efforts to restore the family unit and force the child's custodian, typically lis mother, to the hard choice of ineligibility for assistance or irreversibly widening the gap between parents. Bearing the brunt of the choice is the child, the primary object of public protection under AFDC. Further, it is urged, the rewards of implementing support laws are small. Collections are insignificant. The referral to law enforce-

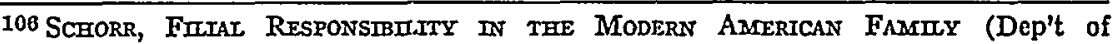
Health, Educ. \& Welfare 1960); Lewis \& Levy, Family Law and Welfare Policies-The Case for "Dual Systems," this symposium; Mandelker, Family Responsibility Under the American Poor Laws, 54 MIcH. L. Rev. 497, 607 (1956); Rheinstein, Molivation of Intergenerational Behavior by Norms of Law, in Soctal STRUCTURE AND THE FaMmY 241-55 (Shanas \& Streib eds. 1965).

10764 Stat. 550 (1950), as amended, 42 U.S.C. $\$ 602$ (a)(10) (Supp. I, 1965). Federal law requires only notification; it does not require that action to locate the absent parent be taken by state agency or applicant.

108 E.g., Irx. Rev. STat. ch. 23, \& 601.1 (1965); see Belknap, An Analysis and Criticism of the Program of Aid to Dependent Children, 6 J. PuB. L. 25, 42 (1957). 100 Taylor, Support from Absent Parents in ADC, 14 Punlic WeIfare 114 (1956). 110 Belknap, supra note 108 , at 44 . 
ment officers is a formal gesture in many places because of the workload otherwise borne by prosecutors' offices, the difficulties of proof and tracing the absent parent, and the lack of enthusiasm for vigorous enforcement. $^{111}$

In short, as in the case of work requirements, the pohicies underlying the requirements of NOLEO are easier to defend than the inconsistencies in administration. AFDC and general assistance, furthermore, in their continued rehance on relatives' responsibility, contrast to other welfare programs with similar avowed purposes of income support. Thus the social insurances make benefits contingent on membership in a class without regard to other family resources. Moreover, experience suggests that application of relatives' responsibility provisions often occurs in families which have a tenuous hold on security, and the deduction of support from the relatives' income depresses their own living standards. ${ }^{112}$

In the case of AFDC, however, parents of minor children, under domestic relations law as well as welfare laws, have a duty to support which no authorities have yet suggested be removed. The essential problem in AFDC is one of practice rather than principle. The accommodation of conflicting values believed to affect family unity is difficult to achieve. And as Professors Lewis and Levy suggest, the abolition of support features under public assistance would result in unequal treatment of families where support is rendered voluntarily and thus calculated in the determination of total need. ${ }^{113}$

The inequities arise from two factors: grossly varying methods of implementing support laws, signifying that a high degree of discretion is often exercised by caseworkers as well as prosecutors; and the reinforcement of support duties by required recourse to law enforcement, a measure not imposed on self-supporting families nor on families who derive income from other governmental forms of income maintenance. We should also note that OASDI records are available to trace the location of the deserting parents, an exception to the general rule of confidentiality which prohibits access by outside agencies or persons. ${ }^{114}$

Resolution of the basic conflicts in policy seems unlikely unless all income maintenance programs take a measure of economic need in family units as a determinant of benefits. ${ }^{115}$ The contributory feature of

111 See id. at 42-45. See also Burans, Soctad Security and Public Policy 80-93 (1956). 112 Rheinstein, supra note 106, at 249-55; Rosenheim, Social Welfare and Its Implications for Family Living, in Soctat Structure and THE Fandex 237 \& nn.65-66 (Shanas \& Streib eds. 1965).

113 See discussion of "substitute parent" policies in Lewis \& Levy, supra note 106, at $761-80$.

11453 Stat. 1398 (1939), as amended, 42 U.S.C. $\$ 1306$ (1964), as amended, 42 U.S.C. $\S 1306$ (Supp. I, 1965).

116 BuRNs, op. cit. supra note 111 , at 92 , 
OASDI renders it improbable that a program of demonstrated need will soon supplant benefits accumulated over time under a program which merely presumes the likelihood of need. At the same time, the general approval of parental support of minor children indicates that the public assistance programs' consideration of parental resources will continue. The infusion of the vagrancy concept is related to implementation-to the required use of law enforcement methods in cases of poor families with deserting parents and to the discretionary standards employed by those charged with administration and enforcement. It is to this level of reform that immediate efforts must be bent.

\section{B. The Female Vagrant in Welfare Law}

The recognition of appropriate policy differences in welfare law based on sex is a matter of recent origin. An historical review of the vagrancy aspect of the poor laws, for example, inakes clear that women, men, and what we today consider children were equally included within its scope. ${ }^{116}$ These measures were directed irnpartially to all though their enforcement may have differed. Indeed, the repeated expressions of concern about public safety which preface vagrancy laws ${ }^{117}$ suggest that the idle male, with his assumed predilection for criminal conduct, was the principal target.

Whatever the historical truth of the inatter, in our own time idleness and the lack of visible means of support among women have been singled out for disapprobation in relatively few and specific instances. From the standpoint of vagrancy offense the "idle" woman summons up the image of a prostitute, drug peddler, or other malfeasant. From the

116 See 1 Nicroris passim. The Statute of Labourers applied to every man and woman "within the age of threescore years." 23 Edw. 3, c. 3 (1349). In 1535, authority was first given for the compulsory apprenticing of vagrant children between the ages of five and fourteen. 27 Hen. 8, c. 25 (1535). Being the child of a vagrant likewise subjected one to compulsory apprenticeship (till age twenty-four for sons, age twenty for daughters, with slavery and punishment for those who rebelled). 1 Edw. 6, c. 3 (1547). Jordan states that the vagrant class contained "a breed of men, their women and their children, [who] had insulated themselves from a society of which they were no more than a festering part." Jordan, Pminanthropy in England 1480-1660, at 79 (1959). In subsequent discussion, however, his references to vagrants are to men. Id. at 79-98.

117 See, e.g., the plaintive preamble to $22 \mathrm{Hen} .8$, c. 12 (1530): "In all places throughout this realm, vagabonds and beggars have of long time increased, and daily do increase in great and excessive numbers, by the occasion of idleness, mother and root of all vices, whereby hath insurged and sprung, and daily insurgeth and springeth, continual thefts, murders, and other heinous offences and great enormities, to the high displeasure of God, the unquietation and damage of the King's people, and to the marvellous disturbance of the common weal." See also Leonard, THe EAriy History of English Poor Relief passim (1900); 3 Stephen, History of the CrIMINal Law of England 391-96 (1883); Webb \& Webb, English Local Governmment: Engeish Poor Law History, Part I: The OID POOR LAW 1-59 (1927). 
point-of-view of welfare, the malingerers and employable women are the prime targets; it is the administrator's duty to keep them off the welfare rolls.

But how do we identify the "voluntarily" idle among women? What welfare policies are suited to prevailing attitudes toward working women? If women are generally regarded either as out of the labor force or as secondary workers, ${ }^{118}$ should it be public policy to insist they be primary workers in the case of the poor?

\section{Working Mothers and $A F D C$}

Consider the confusion of policies surrounding Aid to Families with Dependent Children. It has repeatedly been said that AFDC was established for a needy group which like the other original public assistance categories was outside the labor market. The forerunners of AFDC, we are told, were predicated on the desire to foster the mother's invaluable presence in the home as child caretaker, ${ }^{119}$ and possibly were stimulated in the early depression years by labor's wish to limit the ranks of those seeking employment principally to males. ${ }^{120}$ These Mother's Pension laws were enacted to afford financial aid outside of the almshouse or poor farm for dependent children. ${ }^{121}$

It is not clear, however, whether AFDC, or its precursors, was designed to wholly eliminate maternal employment or to offer an alternative to the prevailing mode of child care for dependent children, namely institutionalization. ${ }^{22}$ We may mislead ourselves by speaking of the history of AFDC as though the original impetus was to provide a

\footnotetext{
118 But cf. Civil Rights Act of 1964, \$§ 703(a)-(e), 42 U.S.C. \$\$ 2000e-2(a)-(e) (1964); note 95 supra.

119 The classic formulation of the case in favor of outdoor relief for mothers and children is found in the initial resolution of the ConfERence on THE CARE of DEPENDENT Chmodren, Proceedings 9-10 (1909). See also U.S. Soctal Security Bd., Social Security IN AMRERICA 233-34 (1937).

120 In many states during the depression mothers were classed as unemployables. Bookman, A Commutnity Program for Reducing Unemployment and Relief, 11 SoctaI SERVICE REv. 367 (1937). This author argues against such a designation for mothers or other groups (that is, those between fifty and sixty-five, the physically handicapped) because of its stigmatizing effect and its deterring the rebabilitative programs which he espouses. Id. at $365-67$.

121 See New York State Comm. on Relief for Widowed Mothers, Report, extracted in 2 Abbott, The Crmo and the State 251-53 (1938).

122 Proponents of Mother's Pension laws stressed the greater expense of the alternative, institutionalization. Id. at 252-55. The Conımission on the Support of Dependent Minor Children of Widowed Mothers of Massachusetts reconmmended that aid be limited to young children in a good family, believing that "the widow without children or with children grown up is in a situation that she can generally manage." Id. at 250 . Note that under AFDC, with its more liberal coverage, the number of one-child fanilies supported was larger tban under Mother's Pension programs. LundBERg, Unto tHe LeAST OF THESE 178 (1947).
} 
choice between employment: and nonemployment. It might better be characterized as offering mothers an alternative to institutionalization of their children or to starvation where employment was not a live possibility or brought insufficient incorne for the entire family. The latter possibility is supported by our knowledge that working women do not represent a new phenomenon, though undeniably our attitudes toward the acceptable reasons for women seeking employment have broadened. Lower-class women generally have been expected to work when the possibility was open to them. ${ }^{123}$

Incoune maimtenance policies respecting dependent children will depend on the issues we frame. Possible alternative policy questions are: Should woinen be supported to care for their children at home and be prohibited from working; should they work and place the children under the care of others; or should they be encouraged to pursue dual careers?

If the history of Mother's Pensions is murky as to permissible answers, current policy is also opaque. The various purposes set forth in the first clause of the AFDC title read:

For the purpose of encouraging the care of dependent children in their own homes or in the homes of relatives by enabling each State to furnish financial assistance and rehabilitation and other services, as far as practicable under the conditions in such State, to needy dependent children and the parents or relatives with whom they are living to help maintain and strengthen family life and to help such parents or relatives to attain capability for the maximum self-support and personal independence consistent with the maintenance of continuing parental care and protection, there is hereby authorized to be appropriated for each fiscal year a sum sufficient to carry out the purpose of this title..$^{124}$

The legislative history of this section is instructive. Originally the statement of purpose read: "for the purposes of enabling each State to furnish financial assistance . . . to needy dependent children . . .."125 The straightforward aim of the federal title was to expand relief measures already on the books of many states. ${ }^{128}$ And so it remained until 1956 when concern for what seemed to be a growing number of

123 Peterson, supra note 95, at 671-73; see also Rossi, Equality Between the Sexes, in TwE WoMan IN Aarerica 615 (Daedalus, Spring 1964) ("for the first time in the history of any known society, motherhood has become a full-time occtpation for adult women": italics

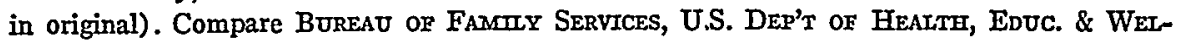
fare, Handboor of Public Assistance Adntnistration, pt. IV, \& 3401.1, expressing very measured approval of mothers' working.

12449 Stat. 627 (1935), as amended, 42 U.S.C. \& 601 (1964).

125 Social Security Act of 1935, ch. 531, § 401, 49 Stat. 627.

126 U.S. Soctad Security Bd., Soctat Security IN Azrerica 233-49 (1937). Congress displayed little interest in this title. Wirte, Tue Deveiorment of the Socul Securaty Acr 164 (1962). 
hard core families on AFDC led Congress to encourage extension of services as well as financial aid. ${ }^{127}$ This had long been the goal of social work. ${ }^{128}$ While a number of states had already made notable efforts to extend services, as distinct from cash payments, to selected public assistance cases, the belief was that services would be broadened if explicitly spelled out in the federal act as a desirable function. Thus came into being the additional phrases: "encouraging the care of dependent children in their own homes" by giving financial aid "and other services"-services not only to the children but also to "the parents or relatives with whom they are living." 129

The expanded concept had an immediate practical effect. Federal matching in administrative costs (in 1956, as before, at the rate of fifty per cent without ceiling) covered social and other specialized services as well as the costs of administering disbursement of money payments and of medical care. ${ }^{130}$ An added incentive to the states was provided by the 1962 amendments-an increase in federal matching for specialized services from fifty to seventy-five per cent. ${ }^{131}$

Parallel changes are reflected in state law. In its general provisions the Ilinois Public Assistance Code declares: "The principal aim in promoting assistance and services shall be to aid those persons who can be so helped, to become self-supporting or attain self-care." Service is to encourage recipients in "developing their self-reliance and realizing their capacities for self-care, self-support, and responsible citizenship." Further, "all public assistance policies slall be formulated and administered with the purpose of strengthening the family unit."132 In the AFDC article the goals of service for this category are enumerated:

"Services" means guidance and counseling provided directly by the staff of the county departments and the STATE DEPARTMENT, or

127 Schottland, The Social Security Amendments of 1956, Social Security Bull., Sept. 1956, pp. 10-11. Background on the amendments is contained in Cohen \& Fauri, The Social Security Amendments of 1956, 14 PUBLIC WeLFARE 183, 193-96 (1956).

128 Belknap, supra note 108, at 33-34.

12970 Stat. 848 (1956), as amended, 42 U.S.C. $\$ 601$ (1964).

130 Schottland, supra note 127 , at 11 .

131 Increased federal participation provides a lever to implement the "new look" provided by the 1962 amendments, 76 Stat. 175, 42 U.S.C. $\$ 603(a)$ (3) (1964), See Editorial, 20 PUBLIC WELFARE 89, 90 (1962). The underlying rationale of the 1962 amendments, and the earlier ones in 1956, 70 Stat. 848 , as amended, 42 U.S.C. $\$ 601$ (1964), is that the poor have many "needs," of which only one is financial; counseling and other services are necessary to lrasten their elevation into the ranks of the middle class. See generally Cohen \& Ball, The Public Welfare Amendments of 1962, 20 PuBLIc WeTFARE 191 (1962); Schorr, The Trend to $R x$, Social Work, Jan. 1962, p. 59; tenBroek, The 1956 Amendments to the Social Security Act, 6 J. PUB. L. 123 (1957). But cf. Mencher, Perspectives on Recent Welfare Legislation, Fore and Aft, Social Work, July 1963, p. 59; Wilson, Public Welfare and the New Frontier, 36 Soctal Service Rev. 253 (1962).

182 Irr. REv. Stat. ch. 23, § 101 (1965). 
through co-operating governmental and private agencies, to assist children and their parents or other adults who provide them with care and supervision in preventing or overcoming financial dependency or social maladjustment; in maintaining and strengthening family life; in increasing the capacities of the parents or other adults for attaining, or maintaining, a decent and healthful standard of living for themselves and the children; and in encouraging and aiding the parents or other adults in providing the children with maximum opportunities for realizing their full potentialities for development. ${ }^{133}$

If we look further into the AFDC portion of the Public Assistance Code we find that establishing eligibility requires, inter alia, "that the parent or parents have met, where applicable, the requirements for employment, or training or retraining for employment, for participation in educational programs designed to enliance opportunities for employment, and for participation in training and service projects." ${ }^{134}$ The ground rules are spelled out in later sections. Significantly, services for purposes other than achieving self-support are not further referred to in the AFDC article.

The tough questions, lowrever, arise in administration. Who qualifies for aid under a program designed to fulfill multiple objectives, at times mutually incompatible? And who determines who will qualify? The answers vary from state to state but some points are plain. First, administrative regulations and manuals provide pertinent sources of information designed to guide the caseworker initially and then his superior in review in determining applicability of the different program objectives. Second, we can be quite sure that no amount of "manualizing" will decide all those cases in which self-support and a mother's presence at lome are twin aims of public policy. Reasonable doubt will sometimes arise as to the priority of one policy as against another, even though statute and administrative interpretation attempt to offer guidance. ${ }^{135}$

133 ILI. Rev. StaT. ch. 23, § 601 (1965).

134 ILL. REv. STAT. ch. 23, \& 603 (1965).

135 Consider the exphit reference in the Illinois Public Assistance Code, Itr. Rev. STAT. ch. 23, \& 605.3 (1965). On employment of mothers, rules and manuals refiect efforts to protect competing interests sensibly. For example, "If a parent who is requesting or receiving assistance for his or her children, or other adult whose needs are included in the assistance budget, refuses to accept available employment for which he or she is qualified, ehibility on the basis of need cannot be established provided that a suitable plan for the children can be arranged during the absence of the parent or otler adult, taking into consideration the age, health, and welfare of the children. In no case shall this rule require consideration of potential employment of a mother or person acting in place of the mother when the youngest child in the ehgible group is less than two years of age." Micr. Socriz Welfare Comar., rule 26a, $\S \mathrm{I}$. Consider Mich. Dep't Soctax Services, Manuat \$ 320-20A: "The primary responsibility and the most important job of any mother is to provide adequate care for her children. Under certain circumstances a mother may be able to provide such care and at the same time work outside the home to support the family. The purpose of this rule is to insure that the ADC program is administered in 
Factors such as past employment experience, work skills, age of children, state of local labor market, and child care resources are among the usual criteria presented for the caseworker's use. The worker's inchnations, informal orders from superiors, guides from agency directors, and public criticism of the program also apparently play a role, perhaps more important than the articulated criteria. ${ }^{\mathbf{1 3 6}}$

Consider, for example, the admonitions and directives to staff contained in the following statements of one state department director:

We need to stress again the vast responsibility which lies ahead in the orderly movement of $\mathrm{ADC}$ mothers into employment or on the path to employment, through education and training programs.

These 45,000 women who are the heads of their families have a dual role-that of homemaker and that of breadwinner. This idea is accepted without a question as a national pattern. There is no valid reason why it should be otherwise. ...

More than 4,000 ADC grantees in the state have finished high school. Their potential is good and they, too, should have a high priority in

such a way as to restore families, whenever possible, to a condition of financial and social independence, recognizing that the majority of families seeking aid are anxious to become self-supporting. The rule apphes to any adult in the assistance group except the mother (or person acting in the place of the mother) of the child under two years of age. In applying this rule an adult is defined as any person who has attained 18 years of age."

And see competing objectives set forth in another state manual with respect to the mother's employment: "(1) The need for the mother's services at home depends upon the number, age and special needs of the children; incapacity of the father; the mother's acceptance of homemaking responsibility; and the availability of a mother-substitute to assure the adequate care of the children at home; (2) Her potential for employment depends upon her training and capacity for employment, the economic feasibility, the job availability and her physical and emotional abihty to assume the dual responsibility of mother and breadwinner." Columbia University School of Social Work: Center on Social Welfare Pohcy and Law, Memorandum on the "social welfare law testing" Function of the Center 15. The Memorandum comments on this regulation: "The regulation may give an initial impression of reasonable guidehines. It does not take much imagination, however, to visualize the kind of opposite results easily reached in the same kinds of cases. Such breadth to discretionary situations translates itself in practice to arbitrary decision-making. There is a need, of course, to avoid rigid rules; and perhaps, in this area, satisfactory guides could not be worked out without incorporating a provision that the ultimate decision as to whether the welfare of her children is better served by staying at home or going to work must be made by the mother."

See also findings and conclusions reported in Cal. Dep't of Social Welfare, Parental Behavior in ANC Families 28, July 16, 1960: "The number of ANC families reported to be having problems in meeting certain program requirements [i.e., reporting changes in income, planning for employment, and participating in rehabilitation plans] suggest the need for further study to determine if these requirements are realistic, unless additional services are available ...." See also Cal. Dep't of Social Welfare, Study of Discontinuance for Lack of Cooperation in the Aid to Needy Children Program, July, 1960, reporting on improper discontinuance of aid in cases where parent refused employment.

136 See policies and practices criticized in D.C. Chapter, National Ass'N Social Workers, The Public Welfare Crisis in the Nation's Capital 33-35 (undated); Memorandum on Social Welfare Testing, op. cit. supra note 135, at 15. 
our endeavor to require recipients to utilize their capacities fully to attain self-dependence.

Looking further, we see that $13,500 \mathrm{ADC}$ grantees have some high school education, and more than 5,000 have finished the eighth grade. This group of recipients, totaling over 18,500 , have demonstrated in their limited academic progress some capacity for achievement. They appear to have average to good potential for either immediate employment, or placement in vocational training classes to learn marketable skills.

The more than 11,000 who have some elementary schooling and the 500 to 600 who have no schooling defy any ready generalization, and the task of elevating many of them to wage earner status may be a lengthy process. For that reason, they should be started toward that goal as quickly as possible.

We will provide you with county-by-county information concerning these 45,000 women, and focus attention on the progress that is being made to accomplish the goals we have set for them. Moving them toward self-support is the first order of business in every county of the state.

The care of the children in the family is a problem to be recognized and solved. Again, let us consider the situation in the light of all working mothers who are faced with the responsibility for planning the care of their children while they are away from home on the job. Some place the children in the care of relatives; some locate a dependable woman to stay in the home with the children or to care for them in her own home; others leave them in nurseries or day-care arrangements. ...

I have mentioned that we will inaugurate education and training programs to reach recipients wherever they live. This is entirely feasible because if public transportation is lacking, other transportation plans can be made. Here again, the situation of public aid recipients is no different from others who must commute to schools and training programs, or to jobs in other communities. We expect aid recipients to do the same.

If jobs cannot be found in their community of residence but are available elsewhere, we will expect them to move-voluntarily or involuntarily. ... Mobility has always been a characteristic of our national culture. We can understand that inclination for people to stay in familiar surroundings, but we cannot condone the continuation of assistance funds to individuals or families in a favored location, when they can become self-supporting by moving to a location where opportunities are better. ${ }^{137}$

The statement underscores the importance of discretion in planning for each AFDC mother. At the same time it reflects a welfare director's

137 Swank, Programs, Trends, Goals, Public Aid in Mlinois 15-16, Oct. 1965. 
determination to hasten acquisition of dual careers by recipient mothers. Both the policy and the practice give rise to serious problems. So long as dual careers are seen as appropriate goals for AFDC mothers, discretion must be lodged in assistance staff in order to avoid the result the program was designed to obviate-automatic insistence on working regardless of personal circumstances. The development of less discretionary standards for determining suitability of employment would appear, by the nature of the relevant criteria, to be exceedingly difficult. ${ }^{138}$ Internal administrative checks and test cases may be useful to curb extreme abuse but unsuited to promoting equality of treatment. So long as a decision hangs on evaluating child care arrangements, for example, the assistance staff must necessarily weigh the child's age, his particular behavior problems, and the quality of adult supervision. The mixture of relevant criteria is complex without even introducing the possibility that other factors may influence the final decision. Furthermore, the enthusiasm of many middle-class women for employment may produce in the staff, itself usually drawn from the middle class, an unrealistic view of the stresses of employment on families headed by one, presumably lower-class, parent. ${ }^{139}$

Thus we face squarely the question of policy. Is it socially desirable that AFDC mothers be required to work or to seek self-betterment by the agency which provides them with income? Why has the question taken on new significance so recently? Here recourse to vagrancy concepts may be instructive. The current stance of the AFDC program is to encourage self-support-and to penalize disinclination to achieve it. This approach contrasts with earlier pronouncements. It may be said that the change stems from today's widespread job opportunities as well as more hospitable attitudes toward women in employment. But in the face of social and economic changes we might well ask why there are unemployed women. Can we not safely assume that relief is an undesired status so far as the recipients as well as the general public are concerned ${ }^{140}$ The reasonable conclusion appears to be that most women on $A F D C$ are unemployed because they are unable to solve child care problems or to find employment. In the latter instance, employment may be foreclosed by the mother's low level of literacy or other personal problems. Society agrees that some publicly mounted attack on these problems is overdue. Granting the existing consensus to promote employment opportunities for the dependent poor, it remains to consider the propriety

138 See warnings in Mapes, The Mother's Employnent-Whose Decision in ADC?, 8 Publtc Welfare 75 (1950).

139 See Belknap, supra note 108, at 40.

140 See Briar, Welfare From Below: Recipients' Views of the Public Welfare System, this symposium. 
of hinging receipt of income upon participation in a plan of living which someone else has concocted. The fact that the good of the individual as well as the social good is the lodestar of this policy does not dispose of the evils of compulsion.

The introduction of compulsion, in fact, strengthens a comparison of these new elements of required "services" to old vagrancy concepts, the more so today when alternative methods of hastening entry into employment can be used. The presence of compulsion leads to the possibility of punitive results, for the choice is between forced training or employment and discontinuance of support. Only "good cause," a concept of uncertain meaning to caseworkers and ill-interpreted to clients, can rescue mothers regarded by their workers as employable. One way to resolve it is to insist "that the ultimate decision as to whether the welfare of her children is better served by staying at home or going to work must be made by the mother."141

To conclude, I would argue that the requirement of participation in work and training, now discretionarily applied to mothers in AFDC families, reflects the old vagrancy concept proscribing idleness without visible means of support. Moreover, in a society which has invented other means to cope with persistent unemployment among the disadvantaged, predicating receipt of relief upon fulfilling this requirement is especially harsh. Rising taxes and fearful recognition of the signs of alienation of nonwhite persons from middle-class values may underlie the emphasis on accelerating self-support. The promotion of self-support among female heads of household should, however, be considered on its own terms and in connection with more general problems of unemployment among the nonwhite. Incorporation of self-support requirements in AFDC obscures consideration of more basic issues at the same time that it reflects the disapprobation of certain groups and statuses which has so long characterized vagrancy.

\section{Morality and $A F D C$}

Similar conclusions may be drawn about requirements respecting personal conduct which permeate AFDC law and administration. The vagrant as a prostitute or person of dissolute character is a notion reflected in the rules relating to the AFDC mother who invites a man into her house, fails to keep a suitable home, or resorts to park or country lane for purposes of extramarital relations. ${ }^{142}$ Comments herein will be limited to the suitable home requirement because of its pervasive influence on AFDC. 
Suitability of the home, broadly speaking, comprehends a range of conduct and environmental circumstances; in practice, however, the term is a euphemism for standards of sexual conduct of the mother ${ }^{143} \mathrm{It}$ should be clearly understood that each state sets its own standard of conduct for the relative with whom the AFDC child resides. Its statutes and administrative regulations must be consulted.

Suitability requirements are a long-standing feature of AFDC laws and the Mother's Pension antecedents. ${ }^{144}$ One state commission investigating the merits of a Mother's Pension law, for example, clearly indicated its intent to hmit aid to families headed by worthy mothers:

The commission rejects the principle of payment by way of indemnity for loss [such as the death of husband]. It proposes the principle of payment by way of subsidy for the rearing of children. The terms "pension," "indemnity" and "compensation" are irrelevant, but the term "subsidy" implies that a condition exists which, aided, will result in positive good for the State. Subsidy makes it feasible that children should stay with their worthy mothers in the most normal relation still possible when the father has been removed by death. It is intended not primarily for those with least adequate incomes under the present system of aid, but for the fit and worthy poor. What a good mother can do for her own children no other woman can do, and no different device can do ....

The commission believes that no aid can be given, except under the poor-law and by private societies, to widows unfit to spend money for the improvements of their families. Aid may have to be given them hesitatingly, without assurance, and under abundant supervision. When even then family life is not really maintained, separation of the children may be resorted to as being genuinely in their interests. Whether it is then best that they be boarded out or placed in institutions must depend on a variety of circumstances. ${ }^{145}$

The fitness test could often be met, for in the period prior to survivors' benefits under OASDI, widows with dependent children formed a large, appealing group among the persons aided by AFDC. ${ }^{146}$ While widowhood is no guarantee of worthiness, the problems of widows

143 Suitable home pohcies almost invariably are applied to homes in which one or more children are illegitimate. Familiar crime-preventive concepts, such as proscription of association with known thieves and prostitutes, could be said to influence determinations of the suitability of home, a required finding in some state AFDC programs. I have never heard of cases where it has been attempted, however, and Bell's study of suitability indicates that the standard is the promiscuity of the mother and/or births of illegitimate children. See BetL, AID to Dependent ChIIDREN 179 (1965). Compare the varied meanings of the "man in the house" rule, listed in Memorandum on Social Welfare Testing, op. cit. supra note 135 , at 25 .

144 BeIr, op. cit. supra note 143, at 3-19.

145 Mass. Comm'n Rep. in 2 AвBotr, op. cit. supra note 121, at 250. (Emphasis added.) 140 Perkins, $A F D C$ in Review 1936-1962, Welfare in Review, Nov. 1963, p. 1, at 7. 
raising young children command more sympathetic attention from the public than the problems of women whose child-care burdens stem from the derehictions of their husbands or their own imprudent sexual behavior. Needless to say, the AFDC program presently draws the problem families most vulnerable to public attack. ${ }^{147}$

By the early 1950 's, social workers, minority group leaders, and others were expressing vigorous dissatisfaction with the use of suitability provisions. ${ }^{148}$ Concurrent with widely publicized attacks on AFDC, state administrations were said to be enploying suitability criteria discriminatorily, based on characteristics of the mothers, and arbitrarily, considering the program's avowed goal of support for needy children. On the latter point evidence was adduced that children found living in unsuitable homes were meligible for AFDC grants-thus deprived of financial aid-but were nonetheless permitted to remain in these allegedly liarmful surroundings. The unfairness of the suitability criterion as applied was urged upon the states to little avail. Finally, a strategy emerged to exploit the conformity requirements of the federal act, with Louisiana as the test state and numerous interested organizations urging abolition of the suitability standard. ${ }^{149}$ On January 16, 1961, after a review of the history of approved state plans with suitable home features, the Social Security Commissioner concluded a finding of nonconformity could not be supported. The following day, lowever, the Secretary of the Department of Health, Education, and Welfare moved to modify the suitable home standard under what is known as the "Flemming ruling."150 Congress followed suit, and as a consequence, states are required to formulate plans of child care for any children living in an "unsuitable" home. ${ }^{161}$ To enable the states to bear the financial burden of foster care, Congress extended payment of AFDC grants to include foster homes and institutions. ${ }^{\mathbf{1 5 2}}$ Participation in these new variants of AFDC rests on the state's enactment of parallel legislation and now includes twenty-three states. ${ }^{163}$

Many state laws are silent on home conditions. Those which take account of them use varying formulae for suitability determmation. In New York State, for example, the agency must find that "the parent or other relative is a fit person to bring up such child or minor so that his

${ }_{147}$ Ibid. See also Mugge, Aid to Families with Dependent Children: Initial Findings, Social Security Bull., March 1963, p. 3.

148 BeII, op. cit. supra note 143 , at 137-51.

149 Ibid.

150 Ibid.

15175 Stat. 77 (1961), as amended, 42 U.S.C. $\$ 604(b)$ (1964). See also 76 Stat. 185 (1962), 42 U.S.C. § 602(a)(13) (1964).

15275 Stat. 76 (1961), as amended, 42 U.S.C. § 608 (1964).

153 Characteristics of State Plans passim. 
physical, mental and moral well-being will be safeguarded, "154 and further that "the rehigious faith of the child or minor shall be preserved or protected." 155 Michigan retains a suitable home requirement but now meets previous objections raised by Washington by assuring general assistance for the child so cut off from AFDC funds. ${ }^{156}$ The net effect of this strategy, it has been claimed, is to produce two standards of support to children in their own homes-one, general assistance, the other, the "ehte" program of AFDC. ${ }^{167}$

Thus the AFDC mother is an object of public disapproval. The desirability of supporting her at home is once again open to question, and her conduct, while in the home and caring for her children, is subject to far greater scrutiny and control than nonrecipients experience. She is the object of "services," for her compulsory, ${ }^{158}$ and of special investigation. ${ }^{159}$

154 N.Y. Soc. WeLFARE LAW § 349 (A) (2).

155 N.Y. Soc. WELFARE LAW $\$ 349$ (C).

158 See BEII, op. cit. supra note 143 , at 150 . This is required by 42 U.S.C. $\S 604$ (b).

157 BELx, op. cit. supra note 143, at 111-23.

${ }^{158}$ See Ily. Public Am Coman's [now Dep't Public Aid], Manuat Redease No. 63.8

(May 15, 1963):

The Illinois Public Aid Commission has always encouraged and expected county departments to offer social services, in addition to financial assistance, to those applicants and recipients who are in need of such services. Provision of stipulated services, as needed and on an individualized basis, is mandatory for all $A D C$ and $A D C-U$ cases and for designated OAA, BA, and DA cases, effective May 1, 1963. Other services may be provided, as needed, when resources for provision of the services are available and staff time permits. (Emphasis added.)

For a discussion of issues arising from the new "service". orientation of public assistance, see Handler \& Rosenheim, Privacy in Welfare: Public Assistance and Juvenile Justice, 31 LAW \& ConTracp. Prob. (to be published 1966).

150 See, e.g., provisions in the Louisiana Manual of Public Assistance which relate to establishing crucial facts of eigibility:

[W] lien the parent applying for or receiving $A D C$ is maintaining or bas maintained a nonlegal marital union as defined above, deprivation of parental support must be established in accordance with 2-740 B. in relation to this parent and this parent's latest nonlegal spouse. (\$ 2-742.1)

....

It is recognized that the client has a right to participate in social activities, mcluding dating. The fact that a mother has dates with a man does not in itself establish that a nonlegal marital union exists. However, the worker shall be alert to and follow up on clues which indicate that the relationship is more than that of dating or courtship.

It is necessary to take into consideration the mother's past pattern of living in evaluating the situation, as well as whether both she and the man are free to marry.

If the mother is not known to have given birth to a child out of wedlock and does not have a past history of nonlegal marital umions; if both she and the man in question are legally free to marry; and if they are together during conventional, or acceptable, hours for dating; the department would not presume that a nonlegal marital union exists. 
She is, in short, a minor criminal-a vagrant, an adulteress, a fornicatorin a nation where criminal laws condemning this kind of conduct have died either through disuse or repeal. The sanctions differ-she suffers no assistance or more restricted assistance instead of imprisonment-yet she is penalized for conduct which in the rest of us is widely regarded to be none of the public's business.

\section{Idle Children as "Welfare Vagrants"}

The school dropout of modern days comes perilously close to the classical vagrant of history. ${ }^{160}$ As commonly described the dropout is male, feckless, and delinquency-prone. From a welfare perspective he represents the tough case which puts to test our public policies respecting support of economically-deprived young people. Should support provided through a welfare system be conditioned solely on age? Or should it, as in the instance of the men and women discussed above, sometimes be made contingent on qualifications of self-betterment or productive ability?

The bulk of children who derive support from public income maintenance are entitled on the bases of age and relationship. Thus under OASDI, to take the largest program, benefits are payable to children who are unmarried (with certain exceptions) and under eighteen (or

On the other land, if either is not free to marry or if the client and the man stay away from home overnight, or he stays in the home to very late hours or overnight, or is in and out of the home at his will at all hours, this is not dating and a nonlegal marital union shall be presumed to exist.

When there is indication that the relationslip may be more than that of normal courtship this slould be discussed with the client, who should be asked for a true and full account concerning the length of time she has been sceing the man in question, where she usually sees him, the frequency of their dates and where they go. (\$ 2-742.2-J) (Emphasis added.)

Special investigation units commonly exist in the large cities with high AFDC rolls, though some state systems also use them. See, e.g., LA. Rev. StaT. ANN. § 46:102(4) (Supp. 1965). The legal questions arising from the practices of these units lave been noted. See Reich, Individual Rights and Social Weljare: The Emerging Social Issues, 74 YaLE L.J. 1245, 1248 (1964); Memorandum on Social Welfare Testing, op. cit. supra note 135, at 5-6. See generally Handler \& Rosenheim, supra note 158 . Federal policy now requires the states to use investigatory techniques that nieet standards of individual dignity and legabty. See Handbook of Public Assistanct Administration, pt. IV, op. cit. sitpra note 123, at $\$ \$ 2220(1), 2230$ (1) (effective July 1, 1967, HandBook TransmittTaL No. 77).

$160 \mathrm{At}$ exactly what age children were considered employable and therefore subject to vagrancy laws if found wandering and idle is somewlat difficult to say. Information is sparse concerning the circumstances of agricultural labor of children, and for the early period under discussion here (fourteenth to sixteenth centuries) the vagrancy problem was associated with supposedly unjustifiable departures from service in husbandry. See 12 Rich. 2, c. 5 (1389) (forbidding apprenticeships to boys and girls who had worked up to the age of twelve in agriculture). In trade, children of very young age were employed prior to the factory systen but the organized trades dependent on apprenticeship appear to have favored twelve or fourteen as minimum ages of entry. DunLOP \& DENMAN, ENCLISI ApprentTCeship and Chmo Labour 98 (1912). 
under twenty-two if attending school) and can show a dependency on an insured individual. ${ }^{161}$ By comparison, AFDC looks to both need and age and permits the states to set more refined qualifications of eligibility.

As originally passed in 1935, the AFDC title identified dependent children as needy youngsters up to age sixteen. ${ }^{162}$ The chosen age coincided with the generally accepted age limit in the states' Mother's Pension and compulsory education laws. ${ }^{163}$ Generally, children under sixteen were eligible for $A D C$ without further qualification. A few states, however, additionally required that the child be regularly attending school, ${ }^{164}$ and Congress adopted this formula when, in 1939, it raised the age of eligibility to eighteen with respect to children in school. ${ }^{105}$ In 1956 the act was amended to eliminate the school attendance requirement, thereby permitting federal matching under state laws which declared children up to eighteen to be eligible. ${ }^{166}$ In 1964 and 1965 Congress once more returned to the age factor. It first permitted inclusion in the grant of children between eighteen and twenty-one who are "regularly attending a high school in pursuance of a course of study leading to a high school diploma or its equivalent, or regularly attending a course of vocational or technical training designed to fit him for gainful employment."167 By the amendments of 1965 the requirements were clarified and now extend simply to students in the named age group "regularly attending a school, college, or university." ${ }^{168}$

Federal and state policies increasingly favor support of youth over compulsory school age who are pursuing their education. This reflects the premium on educational attainment in the modern labor market. Extension of the age of dependency is one method to encourage a youthful recipient, whose employment risks may already be substantial, to complete a course of study which may assure him of a lifetime of productivity. The calculus of assistance reinforces this point; if the average cost of maintaining an eighteen-year-old in school until le reaches twenty-one is, let us say, 912.60 dollars, it is still a small price to pay in order to avoid incurring public aid expenditures for this individual (and his future dependents) over an extended period of time. The cost of main-

16153 Stat. 1364 (1939), as amended, 42 U.S.C. $\S 402$ (d), as amended, 42 U.S.C. § 402(d) (Supp. I, 1965).

102 Social Security Act of 1935, ch. 531, § 406, 49 Stat. 629.

163 U.S. Soctal Security Bd., Socjal Security in Aarerica 235-36 (1937).

104 Belknap, An Analysis and Criticism of the Program of Aid to Dependent Children,

6 J. Pub. L. 25, 35 (1957).

165 Social Security Act Amendments of 1939, ch. 666, § 403, 53 Stat. 1380.

166 Social Security Act Amendments of 1956, ch. 836, § 322, 70 Stat. 850.

167 Social Security Act Amendments of 1964, § 2, 78 Stat. 1042.

16879 Stat. 422, 42 U.S.C. $\S 606($ a) (2) (Supp. I, 1965). 
taining one student for three years is less than the cost of a family of four for eight months. ${ }^{160}$

So much, then, for the arguments in favor of including in a public assistance program youth who are still in school. What of the boys or girls who are over the school-leaving age, out of school, and not seeking employment? (In this inquiry I put aside the question of whether they can find einployment if they look.) Should they be included in an AFDC grant? Should they be required to fulfill additional conditions to qualify?

As far as federal law is concerned, an idle child between school-leaving age and age eighteen is not barred froin AFDC by reason of idleness, and the majority of states also establish age-and age only-as the eligibility factor. ${ }^{170}$ There are still, however, a substantial number of states wlich, even with respect to children under eighteen, require attendance at school as a condition of participation in the grant. As reported in 1964 by the Bureau of Family Services, twenty-one states require school attendance for all children or for those over sixteen but under eighteen. ${ }^{171}$ One state, Texas, excludes all children over age sixteen regardless of educational status. ${ }^{172}$

Welfare policy respecting "productive activity" for youth, especially those in the school dropout class, appears to rest on the conviction that idleness breeds mischief. Beyond this general statement, however, agreement is less apparent. Many commentators emphasize productive activity, whether in training programs or in school, not so much as a means to prevent idleness per se but as a means to enhance personal ability to participate in and thereby strengthen a democratic society. ${ }^{173}$ If one views school dropout rates, however, more as an indicator of school failure than the failure of youth, one can evaluate state policies making inclusion in AFDC contingent on a youth's educational status as doubling the injustice to school dropouts.

169 This calculation is based on personal allowance figures currently used in computing grants in Illinois; in both examples it excludes rent since rent is budgeted (within a maximum) as paid. The child's allowance is 30.80 dollars a month, with an additional 15 cents for lunch. Maintenance until age twenty-one will cost 912.60 dollars for three nine-month school years. A family of four with two parents (30.80 dollars each month), one child between thirteen to seventeen years ( 36.25 dollars) and one child between six to twelve years (27.30 dollars) will require 125.65 dollars a month for personal allowances. The sum for eight months is 1005.20 dollars. Ill. Dep't Public Aid, Monthly Budget Chart (8-7-64).

170 Characteristics of State Plans passim.

171 Arizona, Arkansas, California, Colorado, District of Columbia, Georgia, Idaho, Indiana, Iowa, Kentucky, Louisiana, Mississippi, Missouri, Nebraska, Nevada, New Hampshire, New Mexico, Oklahoma, Tennessee, Vermont, Virginia. Cenaracterustics of State Plans passim.

$172 I d$. at 98.

173 E.g., Conant Slums and Suburbs (1961). 
Suppose we agreed, in contrast to the present piecemeal approach, that needy minors ought to be universally eligible for public financial support. There would still remain the question of whether special conditions should be attached to receipt of assistance. Should youth, equally with the able-bodied male and female adults already discussed, be required to seek employment, to participate in training, or to accept employment or work relief offered thein? What is the preferred attack on idleness in youth?

Initially we should note that public assistance adopts a case-oriented approach which markedly contrasts with the broad-scale "up-grading" approaches to education and training recently adopted under well-publicized federal legislation. Notable examples are the Manpower Development and Training Act, and titles I and II of the Economic Opportunity Act. ${ }^{174}$

Underlying both MDTA and EOA strategies is the conviction that most people, younger and older, including those considered alienated from society, will respond favorably to offers for training which in turn promises employment. Both sets of programs are premised on reaching target populations through voluntary enrollment, reinforced, to be sure, by publicity and persuasion. Sucli criticism as the new programs have received has been focused on inadequate planning or imperfect execution; the principle of voluntary enrollment has withstood the test of operation.

The public assistance approach to able-bodied youth, on the other hand, reflects the characteristic case-oriented approach of other assistance programs, a stigmatization of the able-bodied dependent poor. States that condition aid on school attendance approve support only when it is used to maintain those engaged in socially approved activity. The few anomalous cases requiring work and training referrals for youth between sixteen and eighteen in order to qualify them for an AFDC grant illustrate an informal policy in the same vein. ${ }^{175}$

Treatment of the earnings of an AFDC child provides another dramatic illustration of the policies which pervade all the public assistances. Let me restate the central principle of these programs-relief of need. Need is determined by measuring income and resources available to the

174 See note 41 supra and accompanying text.

175 Consider, however: "Employable youths 16 through 18 years of age, who are not in full time school attendance, are to be referred to Welfare Rehabilitation Service [for training, employment referral, or assignment to work rehef] as soon as assistance is authorized. ... Youths 16 through 18 years of age are given special services by Welfare Rehabilitation Service, but elegibility of the family is not dependent on their cooperation." (Emphasis added.) Cook County Dep't of Pubhc Aid, CCPA Bull. No. 65.1, March 1, 1965:-Notwithstanding the voluntary aspect of the referral, instances of holding up the assistance grant for noncooperation of the youth have been reported to the author. 
recipient and members of his family against a predetermined subsistence budget for the usual items of consumption, possibly expanded under special circumstances. Thus it is argued that to assure equality of treatment of recipients within a state demands that a child's earnings must be deducted from the grant so that similar-sized family units have equal levels of income. If, however, equality of treatment among the recipient class is urged as the value which demands these results, the equality principle here advanced works a discrimination between recipients and nonrecipients who pay taxes on their more substantial incomes: The earnings of the latter are never taxed at a one hundred per cent rate. The equality, then, is confined to the very poor on assistance, and the sentiments favoring it are explicable primarily in terms of limited state appropriations which offer the recipient group a very low level of living. Each dollar appropriated must be stretched if the level is to rise or be maintained. Thus each dollar earned in a recipient family is a dollar of gain for the group as a whole.

Furthermore, even if the equality principle can be defended in its own terms it runs contrary to another value vigorously promoted-monetary incentive as a device for stimulating work. This is the value which attracts enrollees into the newer training programs and which has supported such modifications of assistance policy as have occurred. The modifications have been introduced unsystematically, however, with strikingily disparate results.

Thus, to take the AFDC child, note the different earnings treatments available to or imposed on the states at present. A youth who seeks employment and finds it on his own is a "resource" to his family. His income must be included in the calculation of need unless state law permits disregarding it according to the permissible methods of current federal law. The federal act now allows states to disregard as much as fifty dollars a month per child, to set aside without restriction "earned or other income" for his future identifiable needs, and, besides, to disregard an additional five dollars. ${ }^{176}$ But note, this newest version of the federal act merely sets the permissible limits of state policy. It does not direct state treatment as do the programs of Aid to the Blind or relevant titles of the Economic Opportunity Act. A child enrolled in a Neighborhood Youth Corps program under EOA is entitled to his earnings in full as to the first eighty-five dollars and to half the excess. ${ }^{177}$ Thus within the same family, earnings of two or more children may be treated differently according to their source.

17853 Stat. 1379 (1939), as amended, 42 U.S.C. \& 602(a) (7) (Supp. I, 1965). Note that the fifty dollar and future-identifiable-needs "disregards" apply only to the child. The adult caretaker is not directly benefitted by this policy.

17778 Stat. 534, 42 U.S.C. § 2981 (1964). 
Perhaps the reasonable conclusion to draw is that EOA, establishing a national program, could more readily adopt a liberal policy toward earnings and that the restrictive treatment in public assistance will, by startling contrast, produce its own continuing modification. The area of state decision-making remains substantial, however, and federal legislation of a permissive nature may not be decisive in state legislatures where the size of assistance appropriations is uppermost in the mind. It seems quite possible indeed that differential treatment of earnings will persist. If this forecast proves accurate, the popular attitudes toward able-bodied recipients may be blamed. For the child in his teens no longer looks helpless, appealing, or dependent; he more closely resembles, in popular opinion, the idle, threatening wastrel that his publicly-supported parents are supposed to be, and he is treated accordingly.

III

ELIMINATION OF VAGRANCY CONCEPTS FROM WELFARE IAW: UNFINISHED BUSINESS

I have tried to demonstrate that certain vagrancy concepts significantly mfuse the letter and spirit of welfare programs in the United States today. One may ask, however, "What of it"? Is it inappropriate under the welfare system to accomplish ends which are regarded by many legal theorists as improper subjects of criminal law? Obviously the fact that some have concluded it advisable to eliminate, as an end of the criminal law, the control of conduct not socially harniful does not dispose of the question. For one thing, there are dissenting voices to the proposition as advanced in the context of criminal jurisprudence. More compelling is the point that the goals of welfare law are and should be different from the aims of criminal justice.

Thus we must consider the desired aims of a welfare system in order to evaluate methods demonstrably infused with vagrancy concepts. To say that a welfare system should relieve want and provide services to enhance the competence of individuals in their social and personal functioning is a global way of expressing these aims. It fails to establish, however, the validity of conditions or priorities which are necessary guidelines to fulfillment of the aims. I assume that attainment of universal services is some time ahead, if for no other reason than that our desires exceed our resources. ${ }^{178}$ Income maintenance for all, on the other hand, is immediately attainable if we will it. ${ }^{179}$ Thus with respect to financial

178 With respect to the acute shortage of manpower to provide services, see generally U.S. Dep't of Health, Educ. \& Welfare, Task Force Report, Closing the Gap in Soctar Work Manpower (Nov. 1965).

179 See Schwartz, A Way to End the Means Test, Social Work, July 1964, p. 3 ; cf. Friedman, Capitalisir and Freedom 161-76 (1962). 
support for the needy, its theoretical availability sharpens the issues: Should it be offered with no strings attached? Here we are forced to balance the costs of social policies in considerable ignorance of the probable outcomes. Yet, as the task is undertaken, one consoling point appears. We can at least advance well-informed guesses about the costs of prevailing methods, even if estimates of future results project us into terra incognita. From this point of view an evaluation of vagrancy concepts in the welfare system may be offered.

In his guise as wanderer, the "welfare-vagrant"180 is no more effectively mhibited from moving by existing welfare laws than by the poor law and vagrancy statutes of old. $\mathrm{He}$ is asked to assume consequences, however, which the less mobile among us do not risk, and this result attends in an age when mobility of the able-bodied is a necessary element of modern manpower and labor market policy. Laws whicl elevate the importance of residence, therefore, mirror popular concern about increased financial burdens. Allocation of these burdens, nevertheless, is neither significantly affected nor, I may add, sensibly dealt with by welfare laws which place a premium on residence. Economic opportunity and salubrious climate may well have far more bearing on mobility. The paradox is that laws designed to curb the mobility of undesirables fail in their objective and catch up in their net of residence requirements many wliose characteristics place them among the desirable or worthy group of needy persons.

In the gnise of idle persons lacking visible means of support, the "welfare-vagrants" of today are treated as though work were an occupation which they shun. Yet all attempts to study this assertion belie its accuracy as a generalization. The fluctuations of assistance caseloads made up of the able-bodied bear the closest parallel to fluctuations of the labor market. ${ }^{181}$ Undoubtedly the general conclusion drawn from this fact-that motivation to work coupled with the low levels of living afforded on mcome maintenance generates the observable turnover in relief rolls-is riddled with individual exceptions. Furthermore, past documentation of a parallel between high unemployment and high caseloads for public assistance is no sure predictor that such fluctuations will cease if levels of assistance are raised to approach more closely the wages

180 That is, the able-bodied unemployed; residence laws may have different effects on some public assistance recipients contemplating a move. Studies of assistance caseloads repeatedly demonstrate, however, that most recipients are not newcomers to the jurisdiction.

181 Lynch, Effect of Seasonal Variations in Employment Opportunities on UnemployedParent Segment of Aid to Families with Dependent Children, Welfare in Review, May 1964, p. 10, at 10-14; Perkins, AFDC in Review 1936-1962, Welfare in Review, Nov. 1963, p. 1 , at 9-11. 
offered in low-paid employment. ${ }^{182}$ The significance of these observations for welfare policy, I would argue, is twofold: the necessity of giving special attention to the "hard-core" cases of unemployed persons, and of continued concern for the relationship between prevailing wages and salaries and the level and meclanisms of public income maintenance.

One can hardly escape the conclusion that attitudes toward income maintenance programs for the able-bodied have markedly changed since the inodern programs were inaugurated in 1935. This shift in attitudes has left its mark on both law and practice. Nor should the result surprise us. Welfare in 1930's was seen as a boom for some of the middle as well as the lower class. It was evident to all that suffering was not the exclusive product of individual fault. Blame then attached to the inalfunctioning of a world economy. With universal recognition of the economic causes of poverty, social policy in the 1930's aimed at providing monetary support in as dignified a manner as possible. The stress was on the aged and on the unemployed; other categories were eased in. ${ }^{183}$ In all instances the notion of "riglt" was emphasized and the payment of grants in cash coupled with state plan requirements in categorical assistance and unemployment insurance symbolized a national commitment to preserve a large area of freedom of choice and dignity for recipients who were pawns of fate.

Thirty years later the recipient-beneficiary population among the ablebodied has a new look. Just as Professor Friedman describes the change in the tenant population in public housing, ${ }^{184}$ so too in the welfare system the persons in receipt of funds from AFDC or unemployment insurance are those not benefiting from an improved economy. One popular explanation is related to fault; these people are, it is said, unwilling to work or unable to find employment because of their personal deficiencies. This attitude is expressed in law, as well as in practice. The vagrancy concepts, traced above, include welfare provisions which are creatures of legislation or administrative emphasis occurring since $1950 .{ }^{185}$ Protective payments, work and training programs, the NOLEO amendment-all of these are relatively new and refiect sentiments which are repressive, on the one

182 Cf. Burns, Social Security in Evolution, 39 Soctal SERvice Rev. 129, 140 (1965).

183 See authorities cited in note 126 supra. The clear intention of the framers of the Social Security Act was to establish social insurance as the first line of defense against want, relegating public assistance to a minor and residual role. See tenBroek \& Wilson, Public Assistance and Social Insurance, 1 U.C.L.A.I. Rev. 237, 238 (1954).

184 Friedman, Public Housing and the Poor: An Overview, this symposium.

185 See generally Wickenden, Poverty and the Law: The Constitutional Rights of Assistance Recipients, Feb. 25, 1963; Wickenden, The Indigent and Welfare Administration, in Proceednigs of the Conference on The Extension of Leoal Services to the Poor 41 (U.S. Dep't of Health, Educ. \& Welfare 1964). 
hand, or reformatory, on the other. The danger that the two may merge is well worth noting.

Certain provisions have, of course, been with the programs all along. Suitable home requirements, for one, are old, but what is new is the nature of the population to whom they potentially apply. For such requirements were less threat to the "deserving" poor in 1935; its membership could fulfill the condition. Now, possessing a matured OASDI program, we find that the group remaining on AFDC is, by and large, one ineligible for OASDI. And to considerable degree these "social insurance-ineligibles" are composed of persons whose conduct we disapprove of-the long-term unemployed, the family with an absent parent, the family of the unwed mother. The facts give rise to stereotypes, and these stereotypes generate the pressure for legislative change. Thus we move away from programs offering money payment and emphasizing right toward programs which attach more strings to receipt and expenditure of funds and which proclaim service as an important means toward attainment of self-support. The social pressures for conformity, protection, and economy are manifest in our welfare laws. Undergirding vagrancy throughout its tangled history they now re-emerge in the welfare system.

So far in this article I have argued that the transfusion of vagrancy concepts into welfare programs has for the most part failed to meet the avowed aims of public policy and has had inhuman consequences for individual clients. But a word should be added on the impact of these concepts on the bureaucracy which administers the programs. If the policy adopted toward treatment of the able-bodied is characterized by suspicion and denial, it stands to reason that it takes a toll from those executing the letter and the spirit of the law at the same time that it encourages slyness and chicanery by persons on the receiving end. Harsh measures carry within them the seeds of corruption. At least within the public assistance programs, workers sooner or later become committed to unbending application of the rules ${ }^{186}$ or to most strenuous efforts to avoid intolerably severe consequences. Neither extreme promotes a reasonable consistency in administration nor creates an atmosphere in which legislative and administrative change is freely sought whenever conditions call for it. The caseworkers in many public assistance programs are neither masters of their own small barks nor even confident of safe

186 Bentrup, The Profession and the Means Test, Social Work, April 1964, p. 10, at 15: "Workers not infrequently share with amusement their exploits in 'tripping up' one or another client. Nor does this effect stop with the worker; it has its subtly pervasive influence on the whole administrative structure." See also Blau, Orientation toward Clients in a Public Agency, 5 Admmistrative Sctence Q. 341 (1960), reprinted in Social Wenfare Institutions 654 (Zald ed. 1965). 
passage. Their voyages are subject to the tides of public opinion, the endless waves of manual dicta, and the limits of their own endurance.

In the nature of its difficulties and its triumphs a welfare system is like many other large-scale social systems. ${ }^{187}$ It promotes standardization at a scale once unlleard of. It offers opportunities for aid unknown to earlier times. It also contains unwieldy bureaucratic structures. It has self-perpetuating tendencies and comes to regard its formal functions as limited by those traditionally assigned. Like other social systems, welfare can ill afford to tolerate a single-purpose focus. Instruction as well as income maintenance, counselling as well as clothing, can properly be demanded of this social protection complex. To insist on a restrictive vision of the functions of welfare is to encourage the growth of informal mechanisms and tiers of formal exceptions. In this development would lie the dangers inherent in confusion of purpose and absence of priorities to guide the expenditures of money and talent. Yet multiple purposes must be clearly spelled out and their interrelations articulated.

The vagrancy remnant in the welfare system is at once a symptom of its singlemindedness and a test of its creativity. The criminal and welfare law provisions directed at this shadowy, ill-defined person stigmatize him as an outcast from the mainstream of public life. To alter the impact of either system it is first necessary to recognize the consequences it produces. For the crime of vagrancy this task has been performed, and $I$ have tried to trace the same process of rejection in another area. Yet I cannot conclude without remarking that abolishing the vagrancy remnant in the systems, even though it is limited, poses most difficult problems. ${ }^{188}$ Not all those labelled vagrants are, or have been, poor; neither are all the poor uniformly stigmatized. ${ }^{189}$ Counterfeiters and gypsies and disorderly persons have been vagrants-though not necessarily poor. The aged and disabled who are poor, furthermore, do not seem to bear or feel the full force of the public's scorn. It is the able-bodied unemployedcharacterized as apathetic or rebellious, wanton and irresponsible-who form the target of concern. The persistence of public indignation is perhaps our best indicator of the odds against complete success in replacing untutored emotion with balanced appraisal of policy.

Two commonly encountered solutions to the ills which plague the income maintenances, and most especially public assistance, are the sub-

187 See generally BlaU, Bureaucracy in Modern SocIety (1956); BlaU, The Dynado ICS OF BUREAUCRACY (1955).

188 Cf. Sherry, Vagrants, Rogues and Vagabonds-Old Concepts in Need of Revision, 48 CatrF. L. Rev. 557, 566 (1960).

180 For an enhightening discussion of the stigmatization of the poor, which came to my attention after completing this article, see Matza, Poverty and Disrepute, in Contmarporary Soctal Problems 619 (2d ed. Merton \& Nisbet 1966). 
stitution of more objective principles to guide income distribution to the needy and the separation of service function from financial aid. ${ }^{100}$ Perhaps the merits of these strategies are great; I personally endorse them. But their consequence for eliminating the attitudes and aberrational policies discussed here is problematical. Regardless of the form of payment, programs within the welfare system today reflect differences which can only indicate a general recognition that the various eligible populations differ-at least as publicly viewed. The low levels of grants to AFDC, the persistent lag in bringing unemployment benefits to closer approximation of wage scales, the differential application of services to categories within the public assistances-these are among the signs suggestive of popular distinctions between the employable and the other dependent poor. And past experience indicates that a change in name, a change in form, will not alone suffice to change the content or the modes of public aid. Thus the "welfare-vagrants," whether men or women, young or old, must be faced for what they are-problems to a society which has demonstrated little skill in their solution and little maturity in recognizing its failures. These people squarely pose a test of what the public will freely grant, what it will withhold, and why. In these terms they become appropriate subjects of public debate so that conflicting values are identified, periodically resolved, and once again appraised and re-examined. ${ }^{101}$

For now, the saving grace so far as mitigating the repressive effect of vagrancy concepts on the welfare system may well be the rise of competing programs within the system whose goals are not yet firmly and irrevocably established. As these programs are accepted new ways of handling "problem people" sucl as the vagrant are introduced. By means of developments outside the traditional structure of welfare, there are available various lines of attack on opportunity provision, on work training, on stimulating people to participate in the "Great Society." Such measures, and teclniques yet to receive legislative benediction, present new ways of rehabilitating and reaching the unfortunate people in our land who are lacking in employment, education, parental capabilities, or self-esteem. They also offer leverage to hasten rejection of outmoded concepts. In the last analysis, however, whether the legacy of personal fault or the lure of building multi-purpose systems for a complicated world will shape the future is for the public to say.

100 See Kahn, Social Services in Relation to Income Security, 39 Sociar SERvice REv. 381. (1965); cf. Hoshino, Can the Means Test Be Simplified, Social Work, July 1965, p. 98. See also Mencher, Perspectives on Recent Welfare Legislation, Fore and Aft, Social Work, July 1963, p. 59; Schwartz, A Way to End the Means Test, Social Work, July 1964, p. 3.

191 Wickenden, Welfare Services, in IN Am of THE UNEArpLOYED 252, 270-71 (Becker ed. 1965). 